\title{
Kaingang ethnic territories
}

\author{
Prof. Dr. Ricardo Cid Fernandes ${ }^{7}$ \\ MSc. Paulo Roberto Homem de Góes' \\ 'Universidade Federal do Paraná, Curitiba/PR, Brasil
}

\begin{abstract}
This article presents an overview of Kaingang ethnic territorialization processes in Southern Brazil. Based on historical and ethnographic data, this article analyzes tensions found in the agencyings of territories, emphasizing the resistance of the Kaingang in face of impositions from colonization. The analysis focuses on the different periods of colonial expansion, highlighting the processes of territorial expropriation, conflicts, struggles and negotiations between the Kaingang and different agents of the state. The main objective is to broaden the debates about the importance of the ethnic territories in southern Brazil, based on an appreciation of the perspective of the Kaingang about the processes of territorial confinement and their "retakings" of territories in the past forty years.
\end{abstract}

Keywords: territories, colonization, indigenous policy, retaking, Kaingang. 


\section{Territórios étnicos kaingang}

\section{Resumo}

Este artigo apresenta um panorama dos processos de territorialização étnica nos estados do Sul do Brasil. Com base em dados históricos e etnográficos este artigo apresenta um panorama para a análise da tensão nos agenciamentos de seus territórios, enfatizando a resistência dos Kaingang em face às imposições da colonização. As análises desenvolvidas enfocam os diferentes períodos da expansão colonial, destacando os processos de expropriação territorial, conflitos, lutas e negociações entre os Kaingang e diferentes agentes do Estado. O principal objetivo é ampliar os debates sobre a importância dos territórios étnicos no sul do Brasil a partir da valorização da perspectiva dos Kaingang sobre os processos de confinamento territorial e sobre os processos de retomadas de territórios empreendidos nos últimos quarenta anos.

Palavras-chave: territórios, colonização, indigenismo, retomada, Kaingang. 


\title{
Kaingang ethnic territories
}

\author{
Ricardo Cid Fernandes \\ Paulo Roberto Homem de Góes
}

\section{Introduction}

The Kaingang live in Southern Brazil in areas officially recognized by the Brazilian state. There are 38 Indigenous Lands that have been approved or are in the process of official recognition which, combined, encompass just over 250 thousand hectares. Other locations are undergoing an identification process yet others have had no official measures taken. ${ }^{1}$ There are also Kaingang who live in unofficial areas: encampments in improvised conditions on roadsides or in remote rural areas. Some live in cities in the interior, on rural properties, in state capitals, in urban villages or mixed in with the tumultuous routines of Brazilian cities. They are part of the territory and the population, at least 40 thousand people, one of the most populous indigenous groups in Brazil.

Any generalization about the presence of the Kaingang in Southern Brazil would be limited. The historic analyses, the archeological hypotheses and the ethnographic efforts are not capable of completely encompassing the complexities of the conflicts, the struggles, negotiations and meanings of land to the Kaingang. Nevertheless, in this article we present an overview to analyze tensions in the agencyings of territories, emphasizing the resistance of the Kaingang in response to the impositions of colonization. We risk analyzing the strategies and results attained in processes of long duration, which involve interlinking discourses, institutions, political movements, frontiers and agencies. By definition the study is incomplete, as it is a theme under construction.

The discussion in this article about ethnic territories in Southern Brazil at times gets lost in details and at times is satisfied with generalities. The theme is vast, but focuses on a common point: the Kaingang, and their constant effort to construct their territories. The theoretical perspective adopted follows the notion of the "territorialization process", which operates as a central focus for understanding the historic and contemporary experience of the Kaingang. As carefully developed by João Pacheco de Oliveira (1998), the concept of the territorialization process lends itself to the analysis of the articulation between two distinct orders of phenomenon. On one hand are the political-administrative formulations that mark the action of the nation-state on a defined object such as indigenous communities, which were typically a combination of land and people specific to colonial states. ${ }^{2}$ On the other hand are the identity constructions, which with greater or lesser flexibility refer to the arrangement around ethnicity and its cultural forms. To support the analysis of ethnic territories, this theoretical perspective has the merit of placing side by side categories of the Kaingang and categories of the fóg (the whites or non-Indians, as they say), categories of state and categories opposed to the state.

Conquest - Colonization - Confinement - Retakings; is the series of phases of the Kaingang's territorialization process that will be discussed in this article - although it does not exhaust the issue. In general lines, each phase corresponds to a period: Conquest and Colonization to the seventeenth to nineteenth centuries; confinement concerns the twentieth century and retakings the late twentieth and

\footnotetext{
1 For detailed information about the legal situation of each Kaingang land consult the Instituto Socioambiental which has a regularly updated data base open to public access about the situation of all the indigenous lands in Brazil found at: www.socioambiental.org.

2 As the author emphasizes, this classification is the conceptual basis used by different colonial traditions in definitions such as: "indigenous community", autochthon peoples", "first nations" and others.
} 
twenty-first century. They are generalizations used for the sole purpose of offering a broad frame of reference that can contextualize discussions about the ethnic territories of the South. In this sense, the historic and ethnographic data are presented according to the division of the three states that now compose Southern Brazil: Paraná, Santa Catarina and Rio Grande do Sul.

The considerations about each phase were based on specific theoretical references that contribute to the discussion about the pressures on the Kaingang and their territories. ${ }^{3}$ The analysis of the Conquest and Colonization phase overlaps the results of archeological studies with studies of the "new indigenous history" ${ }^{4}$ or ethno-history. ${ }^{5}$ The analysis about the Confinement phase consists fundamentally in the theoretical-ethnographic approximation to the tensions between the tutelary power of the state ${ }^{6}$ and the indigenous political organization, notably, constructed around the chiefs, or the Pã $i$ Mág as the Kaingang call them. The analysis of the retakings is based on recent ethnographies that focus on the Kaingang's strategies for resistance, confrontation and political articulation in the production of new ethnic rights and territories.

\section{Jê Territories in the South: plateaus and pine trees}

The Kaingang presence in Southern Brazil dates back approximately three thousand years before the present when, through migratory processes still poorly understood, there was a movement of Jê groups from Brazil's Central Plateau to the plateaus of the South (Urban, 1992). Contemporaneously, the Kaingang, along with the Xokleng, ${ }^{7}$ constitute the southern branch of the Jê linguistic family, which pertains to the Macro-Jê linguistic trunk. According to linguistic studies, the historic distribution of the Jê languages began from a Proto-Jê nucleus that subdivided into Jê of the North (northern and central) and Jê of the South, composed of the Kaingang and Xokleng languages. In keeping with this classification, archeological studies demonstrate that the geographic distribution of the Jê of the South has some ecological and morphological similarities with the other Jê peoples (a preference for regions of plains and the headwaters of rivers, the establishment of central and peripheral settlements and the presence of mortuary structures organized in pairs). This is a complex theme that awaits advances in the integration of archeological and ethnological research. ${ }^{8}$

The evidence of the presence of the Jê groups among the first occupants of the meridional territories are related to the occurrence of subterranean houses distributed in agglomerations, funeral complexes and ceremonial centers (Iriarte, 2013; Noelli \& Souza, 2017) that involve sophisticated land engineering techniques. Recent archeological studies demonstrate that the southern Jê occupied these residential

3 There is an impressive bibliographic production about the Kaingang. According to archeologist Francisco Noelli (1998), by the 1990s there were 1,127 publications about the Kaingang, addressing themes such as archeology, history, linguistics, anthropology, education, law and others. Twentyeight years after this archeologist's cataloging efforts the publications have multiplied. It is now reasonable to suppose that there are more than 1,500 published works. Considering this vast production, the bibliographic references cited in this article seek to refer to productions of different generations of researchers, with different institutional affiliations and theoretical perspectives. Inevitably, due to the scope of this article, some important studies will not be cited.

4 As John Monteiro (2001) affirms, "the new indigenous history" encompasses studies, which in Brazil since the late 1970's, combine issues of history and anthropology in the analysis of themes that emerge from the indigenous movement, above all issues related to historic and territorial rights.

5 As Mota and Novak highlight (2013), ethno-history is defined not only by the themes that it addresses, but by a methodology that combines documental sources, oral history and ethnography. Anthropologist Marta Amoroso, who does not define herself as an ethno-historian, upon studying the Kaingang of the nineteenth century, calls attention to the contribution that the concepts of ethnology offer to the ethno-historical analyses (Amoroso, 1998).

6 The development of theory about the tutelary power of the state, developed mainly in the studies of Antônio Carlos de Souza Lima, explores the ways that the state creates a bureaucracy that is ideologically linked to the notion of "pacification" to exercise control over indigenous territories, politics, economies and ways of life.

$7 \quad$ The Xokleng, who in the past were classified as Aweikoma-Kaingang (Métraux, 1946) live mostly in the Ibirama (SC) Indigenous Land. They now call themselves La Klanõ. About the classification of the Jê languages, see D’Angelis 2002.

8 We use "ethnology" to denominate the group of methods (archeological, linguistic, ethnohistoric and ethnographic) used to advance scientific knowledge about a given ethnic group. 
and ceremonial structures uninterruptedly for long periods. ${ }^{9}$ It is significant that while the archeological evidence confirms the long term occupation in the upper portions of the plateau, historical and ethnographic analyses demonstrate that all of the current Kaingang indigenous lands are located to the west of the main archeological complexes studied. The conquest and colonialization forced the abandonment of the underground and ceremonial structures on the mountain plateau of Santa Catarina and the first Plateau of Paraná. This movement to the west, probably placed pressure on other Jê groups that were already established in the plains of the interior, on the courses of the Uruguay, Iguaçu, Ivaí, Piquiri, Tibagi and Paranapanema Rivers.

The archeological studies prove not only the long duration of the presence of Jê groups on the plateaus, but also provide indications that for centuries the Kaingang groups and their ancestors led processes of cultural construction of the landscapes of Brazil's South. The araucária angustifólia (Paraná pine) is a living expression of this culturalized landscape. It is possible to consider, as do ethnoecology studies ${ }^{10}$ about the role of human groups on the formation of the Amazon forest, that the Kaingang ancestors were also responsible for the formation of the araucária forest in the highlands of the South." The Fág (the term for pine in the Kaingang language) is simultaneously the central element of the diet, ${ }^{12}$ and a marker of territories ${ }^{13}$ and the main object (konkei) of the $k i k i^{14}$ ritual - considered the most important Kaingang ritual.

Not by chance, during colonization, the araucária, which is found on the state flag of Paraná, was transformed into a symbol of the "nature" of southern Brazil. As in other regions, to establish a symbolic control of territory, the state sought to dissolve the identities that created obstacles to the construction of the "demographic void", a key concept that legitimates the colonizing project. ${ }^{15}$ The conquest and colonization in the South was the result of successive practices of transformations of cultural landscapes, suppression of ethnic territories and political control over peoples and persons.

9 Studies at a large underground house ( 18 meters in diameter) confirm with radiocarbon dating that there was continuous occupation on the Catarinense Plateau from 1395 d.C to 1650 d.C (Souza J.G. et al. 2016). The same archeological data demonstrate that the abandonment of the large houses only occurred with the consolidation of the "troop trail" in the eighteenth century.

10 Among the researchers who study indigenous groups in Brazil from the ethno-ecology perspective stand out the publications of William Ballée. He explores the importance of botanic species introduced and the formation of anthropogenic forests based on his studies with the Ka'apor Indians and the cabocla communities of the Amazon (Ballée 1994 and 2013)

11 On the process of construction of landscapes on the highlands of Southern Brazil, see Cardenas et all 2015, and the publications of the Jê Landscapes of Southern Brazil project.

12 From the araucária the Kaingang eat the nut, the pinecone, raw, cooked or roasted. The also eat the fág tó ga - the small larva that grows in the tree, which is considered a delicacy. Corteletti (2016) confirms, with archeological studies, that the pinhão [pine "nut"] is part of the Kaingang diet since the occupation of the underground houses.

13 Segundo Becker (1976) the araucária forests were considered to be markers of territory among the Kaingang chiefs in Rio Grande do Sul in the nineteenth century.

14 As Créepau (1997) and others report, the trunk of the araucária is used as a cocho (trough) in which mead is fermented, which is served on the last night of the kiki ritual, the cult to the Kaingang dead.

15 The concept of 'demographic void' as used in the historiography of Southern Brazil was criticized in detail and the deconstructed with the studies and publications of ethnohistorian Lúcio Tadeu Mota. 
Figure 01: Location of the current Kaingang Indigenous Lands in the Atlantic Forest biome and in the context of the Araucária Forest (Almeida 2015:77) ${ }^{16}$. Subtitles: Kaingang Indigenous Lands, Xapecó Indigenous Land, Cerrado Biome, Pantanal Biome, Pampa Biome, Atlantic Forest Biome, Araucária Forest, Plains, K Other types of forest, W Plai

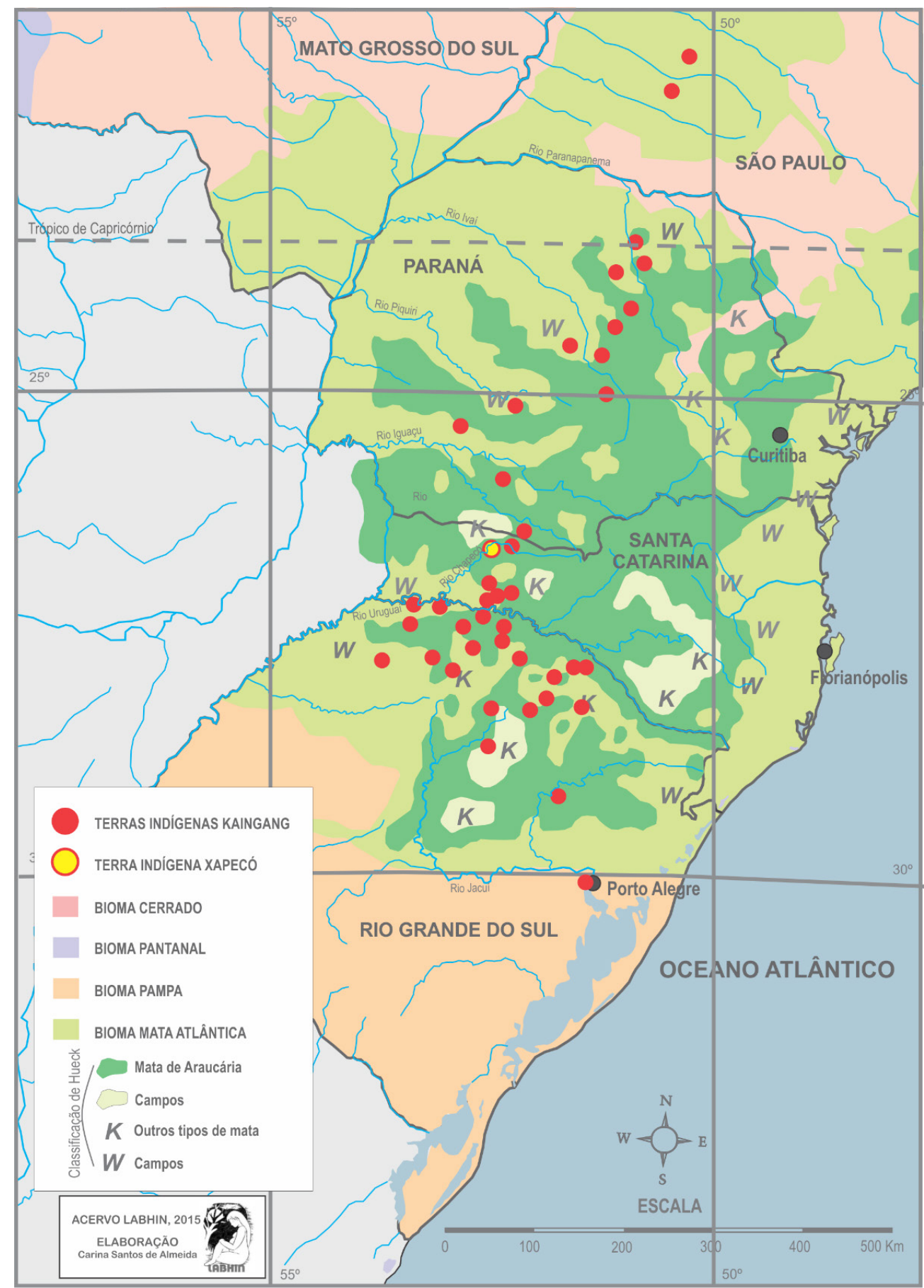

\section{Conquest and Colonization: hostility and "suspension of the effects of humanity"}

The first centuries of colonization were marked by the disputes between the Portuguese and Spanish Crowns and by the Jesuit Mission project. In the early seventeenth century, in the region of the Paraná River, a large colonial and civilizatory frontier was implanted that would include the Ciudad Real del Guaira and the Jesuit Missions. In this region, which is now formed by the countries of Paraguay, Argentina and

16 Source: Prepared by Carina S. de Almeida based on the Mapa de Biomas/IBGE (2004) and Hueck (2015). 
Brazil, missionaries from the Companhia de Jesus dedicated themselves to the catechism and civilizing of the Guarani groups. According to Mota \& Novak (2013), on the margins of the Tibagi, Ivaí, Piqueri and Iguaçu Rivers dozens of Missions were implanted. Also in the early seventeenth century, in the name of the Portuguese Crown and in search of indigenous slaves, bandeirantes from São Paulo destroyed Guaíra and the Reduções. To resist the predators from São Paulo, many "fled to the jungle", others went to the south, together with the priests, to found the Sete Povos das Missões [Seven Peoples of the Missions] ${ }^{17}$ (Mota 1994:70).

In this period arose the first documents that registered a variety of information about the ancestors of the Kaingang. They were identified as groups very hostile to contact. In the seventeenth and eighteenth centuries they were recognized by various denominations, including: Gualachos, Guaianá, Guañanas, Goianás, Guaianas, Kamé, Coroado, Pé-largo, Dorins and Jac-fé. Occupying the fields and forests of the meridional plateau, the Kaingang rejected the policy that sought to attract them to the Missions and to the military encampments. In the first half of the eighteenth century the Guaranitica Wars led to an end of the Jesuit project. The border disputes between Spain and Portugal, as well as the hostility of the Kaingang, caused the region of the southern plateau region, towards the Paraná river basin, to remain "wild" and denationalized until the early nineteenth century.

The axis of Portuguese colonization on the Kaingang territory developed from the east. On the first plateau, close to the coast, in 1704 the Estrada Real [The Royal Road] was constructed, which was initially formed by the land connection between Nossa Senhora da Ponte de Sorocaba and Nossa Senhora da Luz dos Pinhais de Curitiba. Since then, this road has been used as a regular commercial route. ${ }^{18}$ Between 1728 and 1731 this route was prolonged to Viamão (now in Rio Grande do Sul state) forming the Caminho de Tropas [Troop Trail] ${ }^{19}$ Beginning from the Estrada Real and the Caminho de Tropas new trails were opened towards the interior, accompanying the course of the main rivers. Pressured by the advance of the mule trains, some of the Kaingang moved to the west, leaving their territories in the plains regions known as the Campos Gerais, the Campos de Curitiba and the Campos de Lages.

This was the context of the conquest of the Campos de Guarapuava (the Coranbang-R $\hat{e}^{20}$ ) the purpose of which was to "expand the Domains of S.Mage. through the backwoods of this Brazil to the Plata River - using, to do so, the means of winning through industry the time lost" (Franco 1943:41). The discovery of these plains, at the interior of what is now Paraná, occurred with the expeditions of Lieutenant Coronel Afonso Botelho, between 1768 and 1774. The cartography and iconography of those expeditions present a wealth of details that reveal the interest of the colonizers in controlling the lands and peoples of the region.

\footnotetext{
17 The Sete Povos das Missões, installed in 1682 in the northeast corner of what is now Rio Grande do Sul state, was attacked and destroyed by bandeirantes in 1756. This period is generally known as that of the 'guerras guaraníticas'.

18 Although there is no direct equivalence, it is pertinent to consider that the troop trails correspond to the main highways that currently link Brazil's Southern and Southeastern regions over the plateau (part of federal highway BR 116 and state highway PR 151).

19 The caminho de Tropas [troop trail] linked the cities of Viamão (Rio Grande do Sul) and Sorocaba (São Paulo), it was mainly used to transport cattle and goods, including slaves. Along this trail the encampments and starting points of the mule teams were transformed into ranches and cities that until today are points of reference in the southern region. In addition to the consolidation of the commercial route, the mule teams are at the base of a way of life that is highly valued regionally, associated to animal husbandry, especially horses and to a certain ethos that approximates the personalities of the pioneer, the bandoleiro [bandit] and the merchant.

20 According to the translation by Borba (1908) Coranbang-Rê corresponds to the 'campo da grande clareira' [plain with the large clearing], see also Weisemann 2011
} 
Figure 02 Carta chorografica from the expedition of Afonso Botelho - [1772] identifying the Iguaçú [Rio Grande], Rio D. Luíz (Ivaí) and Tibagy Rivers. (Source: Franco, 1943, Ed. Museu Paranaense, Curitiba.)

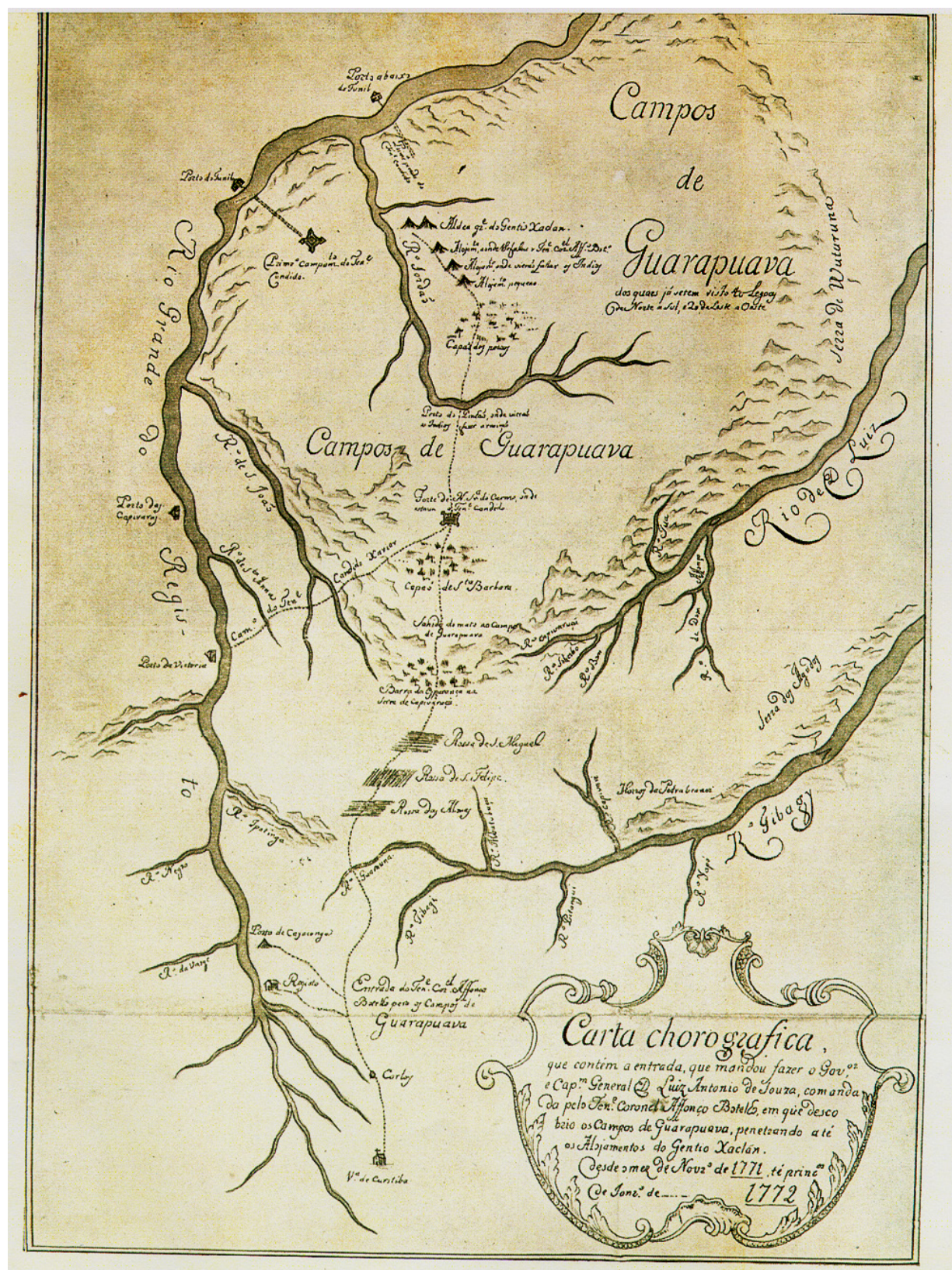

The Carta Chorográfica identifies the trajectory ${ }^{21}$ traveled from the Vila de Curitiba, passing through the headwaters of the Iguaçu, Ivaí and Tibagi Rivers, to the village of Gentio Xaclan..$^{22}$ The records of the expeditions are not limited to the notations and the cartography. Forty designs, attributed to Joaquim José de Miranda, in gouache and watercolors portray the encounters of the colonizers with the indigenous. It is a precious archive that presents, with naturalist inclinations, an illustrated narrative of the first contact: portraits of indigenous men and women, of the villages, the fauna, the plains and rivers, of military encampments, of men in uniform, armed and religious men and of conflicts.

21 This trajectory corresponds, approximately, to the current route of federal highway BR 277.

22 The linguist Wilmar D'Angelis demonstrates that the spelling "xaclan" corresponds to a pronunciation in xokren, indicating an evident proximity with the current Xokleng, without denying the pertinence of the classification to the Jê from the South (communication RAM 2007/UFRGS Porto Alegre). 
Figure 03 Print 36: Conquest of the Guarapuava plains (Amoroso et al., 2003)

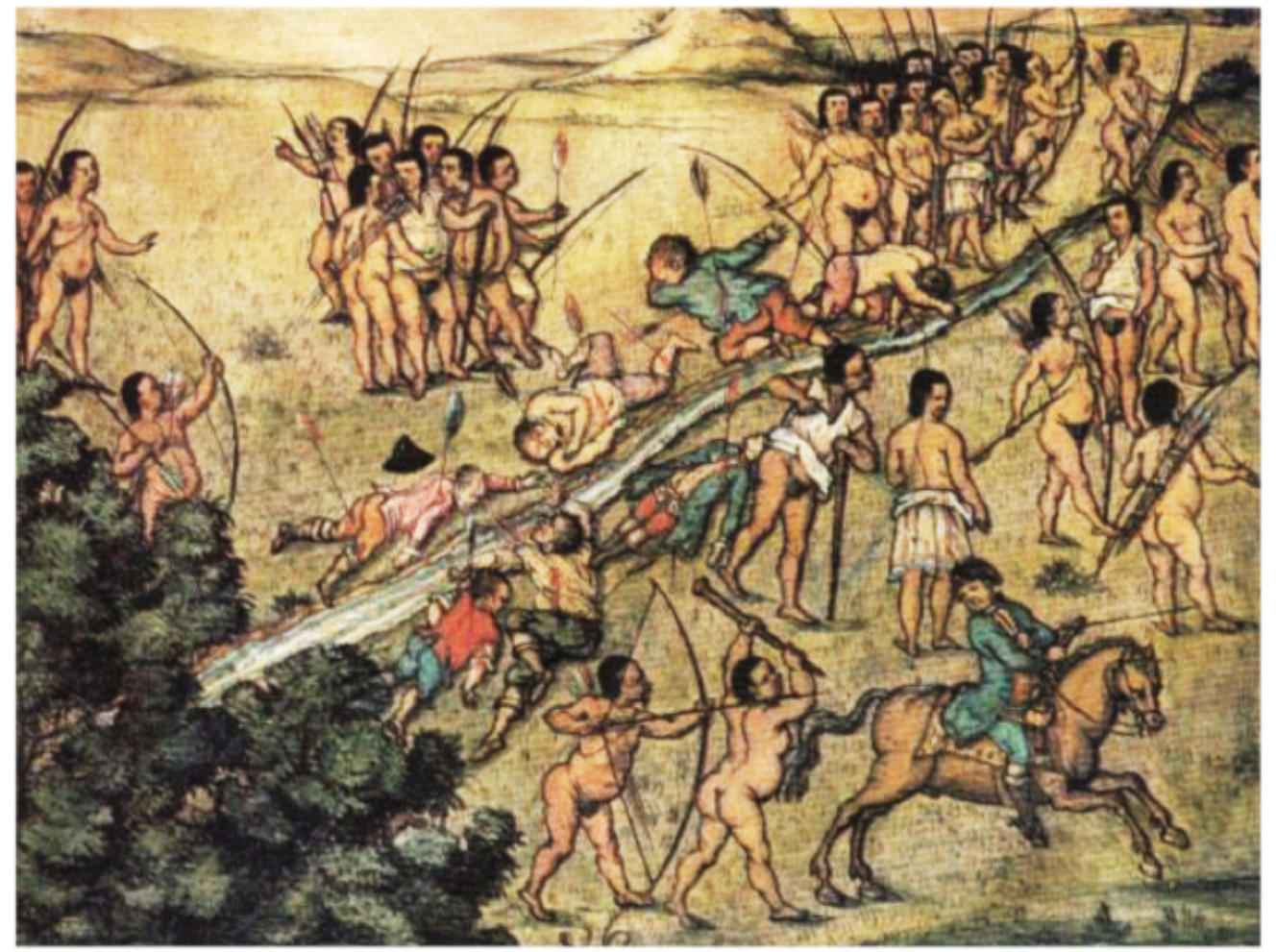

Figure 04 Print 38: Conquest of the Guarapuava plains (Amoroso et al., 2003)

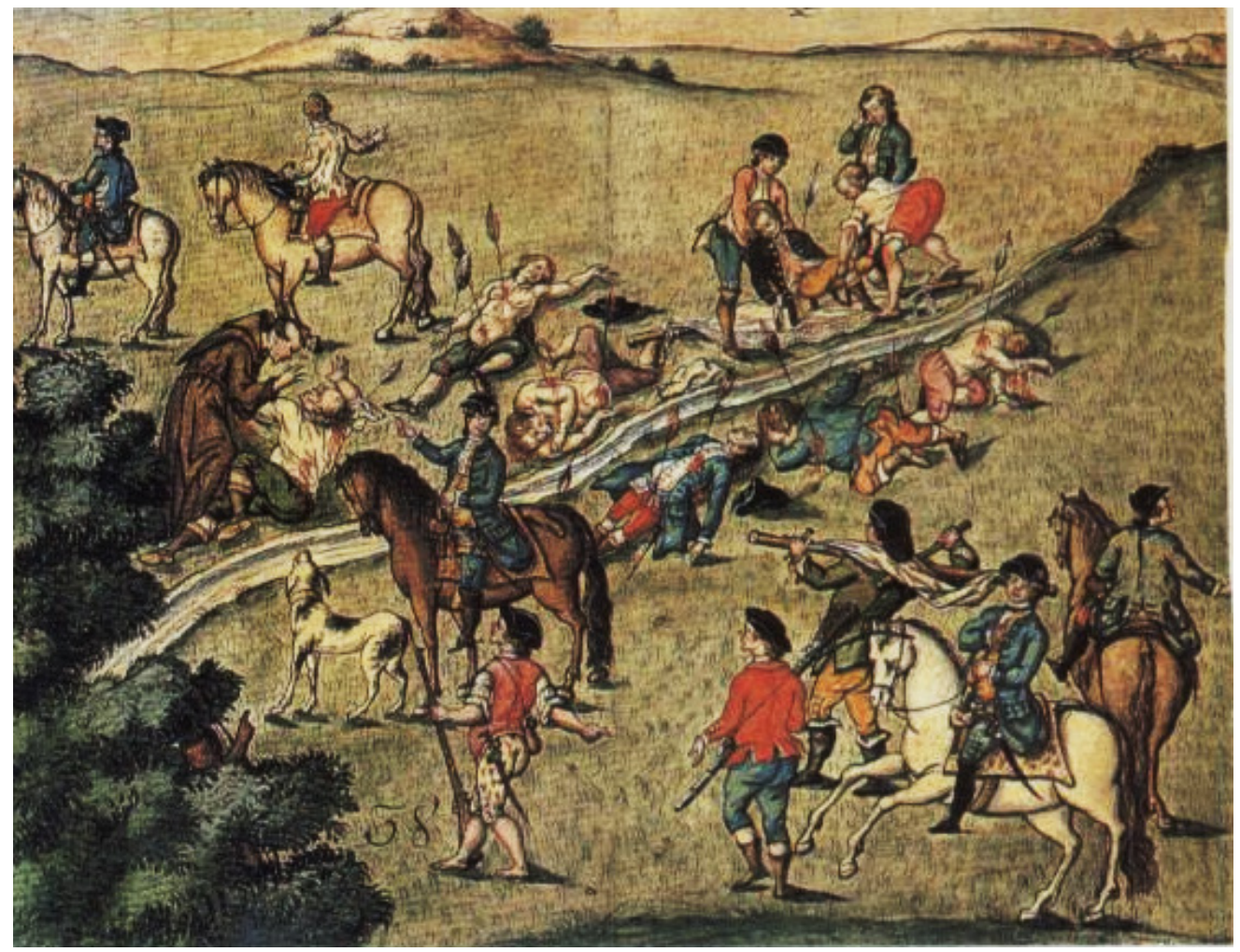

The expeditions of Afonso Botelho did not guarantee the permanence of the colonizers in the region. The troops were expelled by the Kaingang. ${ }^{23}$ Nevertheless, the recognition of these territories was decisive for subsequent colonial initiatives. To the north of Guarapuava, there were constant movements of

23 The violence of the encounter was portrayed in three canvases. Prints 36 and 38 depict indigenous shooting arrows against wounded and dead soldiers. Print 39 was not recovered, but its caption says: "' (Aoki, 2013:32). 
expansion over the Kaingang territories. Since the 1720's, people from São Paulo living in the Curitiba plains requested lands on the plains to the right of the Tibagi River. The colonization of this region, however, took place only after 1780 through the actions of José Felix da Silva and the establishment of the Fortaleza farm, located on the right bank of the Tibagi River. In 1820, French naturalist Saint-Hilaire, on a visit to the farm, described the context of the conflicts in the late eighteenth century:

Fortaleza was, at the time of my trip, the farm that was found more deeply encrusted in the lands occupied by the savages. They frequently caused disorder, they were chased, they killed some men, imprisoned women and children. The blacks of José Felix da Silva would never work on the plantations without being armed. The Indians neighboring Fortaleza belonged, as did those of Jaguariaíba, to the Coroados tribe (Saint-Hilaire, 1995 [1851]: 60).

At the time of the visit, José Felix was the owner of the Fortaleza and of four other areas that, according to Saint-Hilaire, totaled, 80,000 alqueires (aproximately 200,000 hectares). Part of his wealth was obtained from the Portuguese Crown in recognition of the territorial conquests from the savages. In 1796 José Félix coordinated an act of revenge against the Kaingang - the "Tibagi massacre".

José Felix, together with his militiamen and slaves, chased and massacred wild Indians, coming to decimate hundreds of Cainguangue families (...) he reports that there was so much blood (...) that the nearby stream was dyed red and came to be called the River of Death" (Coraiola, 2003:28)

The location of the massacre, denominated "Mortandade" [death or slaughter in Portuguese], near the Tibagi River, is the current center of the pulp companies in the municipality of Telêmaco Borba. It does not fail to be tragically ironic that the place known in the eighteenth and nineteenth centuries as "Mortandade" was renamed, in 1941, by the family that owned the pulp companies, as "Harmonia".

In the early nineteenth century, forty years after the expeditions of Afonso Botelho to the Guarapuava Plains, and amid the massacres that marked the opening of the troop trails, the occupation of the Portuguese settlers of the Kaingang territory gained significant impulse: the coming of the Royal Family to Brazil. In 1808, the year of their arrival, Dom João VI drafted the Carta Régia to order his subjects.

Being aware of the near total abandonment, in which are found the general plains of Coritiba and Guarapuava, as well as all the lands that flow into the Paraná and form on the other side the headwaters of the Uruguay, all within the limits of this Capitania and infested by the Indians known as Bugres, who cruelly kill all the farmers and landowners [...] under the fair and human laws that guide my people, and even demonstrating the experience of how useless is the defensive war system: I am served by these and other just reasons that suspend the effects of the humanity which I had determined they be treated, I order you: First, as soon as you receive this my Carta Regia, you should consider to be initiated the war against these Indian barbarians: that you should organize in bodies those militiamen of Coritiba and of the rest of the Capitania of S. Paulo who voluntarily want to take arms against them [...] which you will have understood and execute as you are ordered herein.

Written in the Palace of Rio de Janeiro November 5, 1808. PRINCE

The orders to "suspend the effects of the humanity" towards the Kaingang and to "consider to be initiated the war against these Indian barbarians" synthesizes the determination with which the Portuguese Crown treated the colonization of the region. The Kaingang territories, the plateaus and pine trees, which had marked a field of hostilities to the missions, bandeirantes and troopers, was, by the act of the Crown, transformed into a territory of war to guarantee the conquest and colonization.

In 1809 the expedition of Lieutenant Coronel Diogo Pinto de Azevedo Portugal began from São Paulo and headed towards the Guarapuava Plains, where the Atalaya Fort would be mounted. Among 
the more than dozens of soldiers in the expedition (Mota 1994:128) was the priest Chagas Limas. The chaplain of the expedition was concerned with the polygamy and potions of the indigenous peoples. His impressions are registered in the Memórias sobre o Descobrimento e Colonia de Guarapuava (1976 [1842]) which discusses the "hoards", "corporations", "tribes" and "Nations" of "Votorões", "Cayeres", "Camés", "Xokrens" and "Dorins". ${ }^{24}$ His comments are replete with information about the massacres and resistance of the indigenous peoples who, together with their chiefs, either joined the colonizers and accepted the catechese, or fled to the Sertoens [backwoods] and attacked the Fort. For Chagas Lima, the most important and influential chief was the indigenous baptized with the name of Antônio José Pahy. The Memória de Chagas Lima offers our time impressions about the ancestors of the Kaingang and about the power that they had over the plains and forests of the region. The description of the landscapes and of the routes along which the priest lived for more than twenty years is accompanied by descriptions of dos gentios [Gentiles]: their names, manners and character. Chagas Lima discovered and described an ethnic territory.

In the late 1830's, with the Descobrimento e Colônia de Guarapuava [Discovery and Colonization of Guarauava] already consolidated, there was a new expansion of colonization to the north and west. Under orders of the Barão de Antonina, a safe route was open in the direction of Mato Grosso, over the natural courses of the Tibagi, Paranapanema, Ivinhema and Brilhante Rivers. In 1851, the Military Colony of Jataí was created in the sertão of Tibagi and then the villages of São Pedro de Alcântara $(1855)^{25}$ and São Jerônimo (1859). For the Barão de Antonina the relationship between the Military Colony and the village presupposed mutual cooperation, aimed at security through pacification of the Kaingang who lived in the region's forests. ${ }^{26}$

The expansion to the south, begun in 1840 , also involved the creation of military colonies, located at the margins of the rivers and at the proximities with Kaingang groups. ${ }^{27}$ One of their objectives was to dominate the routes to the Missões region, to control the borders and definitively nationalize the meridional territories. The Kaingang groups from Guarapuava served as guides, interpreters and mediators in the colonization processes of the Palmas and Nonoai plains. ${ }^{28}$ In this process were created the first villages for the Kaingang in the province of São Pedro do Rio Grande: Nonoai (Nonoai Plains), Guarita (Campo Novo) and Ligeiro (Campo do Meio). In 1856, the limits of the Indian Lands in Nonoai were defined, which totaled "1o léguas em quadrado" [ten square leagues] (Becker, 1976:61) - the equivalent of 428 thousand hectares, the first official numbers of the process of ethnic Kaingang territorialization.

As part of the colonization and nationalization plan for the territories in Southern Brazil ${ }^{29}$ in the second half of the nineteenth century the land policy of the Imperial government officially defined the first

\footnotetext{
24 The name Kaingang had only been used since the late nineteenth century, with the writings of Telêmaco Borba (1882). During the nineteenth and early twentieth century the name Coroado was widely used. The term refers to the haircut in the form of a crown [coroa in Portuguese] (Mabilde, 1983).

25 The village of São Pedro de Alcântara functioned from 1855 until the death of Frei Timótheo de Castellnovo. Telêmaco Borba was the administrator between 1863 and 1873 (Amoroso, 1998).

26 In 1847, before the creation of the military colony, the Barão de Antonina brought dozens of Kaiowá families from the Ivinhema and Iguatemi Rivers to the village, initiating the establishment of the Kaiowá in the region (Amoroso, 1998).

27 Colônia Militar do Chopim and Colônia Militar do Chapecó [Military colonies], respectively, close to the current indigenous lands of Mangueirinha (PR) and Xapecó (SC).

28 The best known mediator was the Indian Vitorino Condá who, upon leaving Guarapuava, was hired in 1847 by the government of the province of Rio Grande do Sul to act in the settling of the Kaingang who were spread through the Nonoai Plains. To do so, "in addition to the food and clothes offered, it was also agreed that "a monthly gratification of $50 \$ 000$ reis would be granted as soon as the village reached 500 souls." (Relatório do presidente da Província em $05 / 10 / 1847$ apud Laroque 200o: 112). Condá was a member of the 'Companhia dos Pedestres' - a police force charged with keeping the Indians within the limits of the village of Nonoai and "having them [the Indians] see that those people [the directors of the village] are there to protect and help and at the same time to chase them through the forests, when they try to escape"(Nonnenmacher 2000:20).

29 It is important to remember that the borders between Portugal and Spain in the América Platina were marked by the Treaty of Madrid (1750) and the Treaty of Santo Ildefonso (1777) and that because of imprecision in the cartography, the definition of the southern frontier was defined by rivers that do not meet, that is the Iguaçu and Uruguay rivers. This imprecision is at the origin of the dispute between the colonial metropoles and later between independent Brazil and Argentina. The solution for the "Questão de Palmas", as the problem of the Brazil-Argentine border was known, was only determined in 1895 .
} 
areas reserved for the indigenous, all of them for the Kaingang. This was a state policy aimed at the ethnic Kaingang territory. It is important to highlight that in this period there was no policy to reserve lands for other ethnic groups who, although in smaller numbers, also lived in Southern Brazil, such as the Jê do Sul (Xokleng, who now live in Santa Catarina), the Guarani (who were associated to the Spanish colonies and now live in the south, southeast and midwest of Brazil and also in the neighboring countries of Argentina, Paraguay and Bolívia), the Xetá (who were definitively contacted only in the 1950s, in northern Paraná) and the Charrua and Minuano (who are associated to the Plata River region and to the south of Rio Grande do Sul state). For the Kaingang, the nineteenth century policy of reserving lands established rights while it simultaneously imposed severe limits to the traditional forms of occupation and circulation through their traditional territory. For the state, the policy sought to free land for colonization. This process was not declared a Guerra Justa [Just War] and did not involve the suspension of the effects of humanity. The legal and institutional framework was the Land Law (1850) and the Regulation of the Missions ${ }^{30}$ (1845), mechanisms of the national state to implement control over the indigenous communities, a political-administrative object that synthesized the combination of the land and the people.

In Southern Brazil, the official recognition of indigenous areas in the second half of the nineteenth century is the mark of the policy for territorial confinement. For the Kaingang, this was a critical period of conflicts and wars in all regions. Many historic documents from this period register the action of the Kaingang chiefs, the Pã́i Mág, in their negotiations with different colonial agents (directors of the Indians, missionaries, engineers and naturalists)..$^{31}$ The power of mediation of these Pã̃i Mág in the defense of the Kaingang territories is interpreted with all the ambiguities of the colonial historiography. As in other parts of Brazil, some indigenous leaders were classified as collaborators and allies, others as aloof, hostile and fierce..$^{32}$ In all cases, in all the records, the Kaingang chiefs appear at the center of the disputes, discussions and agreements about the reserved lands. In the nineteenth century, and until today, the strengthening of their political power is the Kaingang response to the territorial confinement policy.

\section{Confinement: the delimitations and reductions of the areas reserved for the Kaingang}

In the early twentieth century, in the first years of the Republic, still before the creation of the Indian Protection Service, ${ }^{33}$ the state governments of Paraná and Rio Grande do Sul issued decrees regulating the reserve of lands for the indigenous. ${ }^{34}$ In Paraná, between the years 1900 and 1915, decrees were promulgated reserving lands for the Kaingang in the regions of the Ivaí, Chapecó ${ }^{35}$, Iguaçu and Tibagi Rivers. ${ }^{36}$

\footnotetext{
30 The "Regulation about the Missions of Catechism and Civilization of the Indians" (Decree №. 426, of 24/07/1845), the main indigenous legislation of the nineteenth century, establishes guidelines that were more administrative than political for governing the Indians on reserves. (Carneiro da Cunha, 1992:138) 31 About the action of the Kaingang leaders in the nineteenth century the studies of historian Luis Fernando da Silva Laroque should be mentioned. He identified each Pã’i Mág, their territory of action, alliances and conflicts based on documental sources of state governments of São Paulo, Paraná, Santa Catarina and Rio Grande do Sul. For an ethnological analysis of the Kaingang Pã̉i Mág see Fernandes 2003 and 2006.

32 As John Monteiro (1992) affirmed, the classification in allies and aloof, tame and fierce, Tupis and Tapuias, which accompanied the historic records are used in the construction of the discourse about Brazil's national identity.

33 In 1910 the Indian Protection Services and Location of the National Worker, it was renamed in 1918 as the Indian Protection Service (SPI), a nomenclature that would last until 1967, when the National Indian Foundation (FUNAI) was created.

34 Because of the limits of this article, the presence of the Kaingang who now live in São Paulo state, on the Vanuire and Icatu Indigenous Lands, together with the Terena and Krenak Indians, will not be examined. These cases involve equivalent processes that also involve the institutional action of the Indian Protection Service in the regional context of the interior of São Paulo state.

35 Until 1916, the territory of the current state of Paraná included what is now the western portion of Santa Catarina, a region where the indigenous lands are located. The dispute for the control of these lands was one of the reasons for the conflict known as the War of the Contestado, between 1912 and 1916.

36 The indigenous land of Mococa was not the object of state decree. In this case, the regularization was conducted through the granting of title in the name of Capitain Timóteo, chief of the tribes of the Coroados (Mota \& Novak 2013:98).
} 


\begin{tabular}{|c|c|c|c|}
\hline & Year & Area & Location \\
\hline Decree $N^{\circ} 6$ & 1900 & Apucarana & Rio Tibagi \\
\hline Decree $N^{\circ} 8$ & 1901 & Faxinal and Ivaí & Rio Ivaí \\
\hline Decree $N^{\circ} 6$ & 1901 & Rio das Cobras & Iguaçu \\
\hline Decree $\mathrm{N}^{\circ} 7$ & 1902 & Xapecó & Rio Chapecó \\
\hline \multirow[t]{2}{*}{ Decree $N^{\circ} 64$} & 1903 & Mangueirinha & Rio Iguaçu \\
\hline & 1903 & Mococa $^{36}$ & Rio Tibagi \\
\hline Decree SPI 8.941 & 1911 & São Jerônimo & Rio Tibagi \\
\hline Decree $N^{\circ} 591$ & 1915 & Queimadas & Rio Tibagi/Ivaí \\
\hline
\end{tabular}

The first Decrees referred directly to the chiefs, the territorial limits, to the terras devolutas [unused public lands] and to the rights of third parties:

To settle the indigenous Coroado tribe, under the leadership of Paulino Arak-xó and Pedro dos Santos and other tribes, the terras devolutas located between between the Peixe or Ubásinho River, will be reserved from its headwaters to its mouth at the Ivahy River, from this river until the mouth of the Jacare river, from this to its headwaters and to the peak of the mountains of Apucarana in the municipality of Guarapuava. (Decree no 8 o9/09/1901). [The current Faxinal and Ivaí Indigenous Lands]. Emphasis ours.

To settle the indigenous Coroado tribe under the leadership of Chief Vaincrê, respecting the rights of third parties, an area of land with the following limits will be reserved: from the Chapecó River, from the road that runs to the south, to the pass of the Chapecozinho River, and from these two rivers until where they form a bank." (Decree n.7 of 18/06/1902) [The current Xapecó and Toldo Imbu Indigenous Lands]. Emphasis ours.

To settle the indigenous tribes the lands occupied by the cabildas of chief Cretãn will be reserved with the following borders: from the headwaters of the Lageado Grande River to the headwaters of the Palmeirinha River and from these two rivers down to the Iguassú, which will be the northern border, respecting the rights of third parties (Decreto no 64 de 02 de março de 1903). [Current Mangueirinha Indigenous Land]. Emphasis ours.

With these decrees, the state recognized territorial rights that are explicitly related to the chiefs. The action of the leaders deserves attention, not only because they were leaders in wars and negotiations, but also, because among the Kaingang there is a long lasting association between certain surnames and lands: the Cretã in Mangueirinha; the Vegmo and Ferreira in Queimadas; the Cândido in São Jerônimo; the Pereira in Mococa; the Viri and Mendes in Palmas, the Braga in Ligeiro. A Kaingang version, which conflicts with the determinations of the tutelary power of the state, imposes a definition that is culturally specific to the pairing of land and people that is at the center of the territorialization process. The Kaingang surnames are used until today. They are part of their criteria of territorial belonging and political legitimacy.

The recurrence of the surnames associated to certain lands refers to a suggestion of Curt Nimuendaju about the class of pai leaders:

Outside the Canella I have encountered nothing at all suggestive of this hamrén institution except among the Kaingang in the Rio lvahy district (state of Parana). Here there are at least three classes (p. 82-) pai, votóro, and péniye, the first ranking highest (cf. Guarani : pai, a person of prestige) and comprising the chiefs. It enjoys ceremonial prerogatives, such as sitting on a white caraguata blanket; and is credited with a peculiar sensitivity to harmful influences. For that reason, the chief Vegmo' told me, he had bestowed on his naturally feeble son a péniye rather than a pai name (Nimuendaju 1946:98).

Many contemporary Kaingaing indigenous lands originated from initiatives of these leaders, who beyond being mentioned in the text of the decrees, represented before the state the honor of the ancestors. 
This was the expression used by the chief of Mangueirinha Ângelo Cretã, when in 1975 he explained to anthropologist Maria Lígia Moura Pires about the origin of the right to land. He said: Then this land was purchased. The government did not give it to us. In those times, my grandparents earned this with honor. This was not given to us a present, no. My grandparents sweated and suffered to earn this (Castro 2011:51). The indigenous narratives that attest that the current Indigenous Lands were not "donated" or "recognized" but "purchased" from the government are in fact, common among the Kaingang.

Capitão Ozório, speaking about the expedition of a committee of the Indian Protection Service, in 1910, through the villages in the region of Tibagi (Mota \& Novak, 2013) made clear that even as a representative of a recently created agency, he was pressured by Kaingang leaders to assume responsibility for the invasions of the indigenous lands. Ozório registered the harsh statements of the Kaingang leaders against the theft of lands. Four years after their first passage through the villages of Faxinalzinho and Faxinal do Cambará the government of Paraná state issued Decree 59, of 1915, "which reserves an area of land for the settlement of the Kaingang Indians". This decree corresponds to the origin of the current Queimadas Indigenous Land.

With the decrees of the state governments, the lands of the southern plateau came to be mapped to serve the territorial order of the state. The Kaingang cultural landscape, its rivers, plains, mountain peaks and forests were irremediably affected by the colonization. The reference to terras devolutas confirmed that for the state, this was not an ethnic territory or a cultural landscape to be protected, but unoccupied areas to be colonized. The demographic void and nomadism of the indigenous peoples were, and still are, theses that, although notoriously false, are strongly defended by the land policy of Southern Brazil.

The right of third parties, referred to in the Land Law (1850), was also invoked to reduce the dimensions of the lands reserved to the Kaingang. In the case of the lands for the indigenous, under the leadership of Chief Vainkre, the current Xapecó Indigenous Land, Decree № 07, of 1902, reserved more than 50,000 hectares bordered by the Chapecó and Chapecozinho Rivers and by the telegraph line. However, in the following years, because of recourses to third party rights, these borders were changed, reducing the size to approximately 14 thousand hectares. ${ }^{37}$

With the lands officially recognized, the process began for systematic control over the Kaingang policy. Through the Indian Protection Service (SPI), by means of the $7^{\text {th }}$ Regional Inspectorate, located in Curitiba, and the action of the Indian Delegates, the tutelary power of the state was organized. Politically and administratively, as defined by Antônio Carlos de Souza Lima, the Indian Protection Service implemented A Grand Encirclement of Peace. ${ }^{38}$ In name of Indian protection and seeking to transform the Kaingang into national workers, the tutelary power was exercised through their concentration in settlements and villages, a weakening of the political power of the Pã́í Mág, by control over the work and economy of the families and through the prohibition and persecution of ritual and religious practices. ${ }^{39}$

The tutelary policy of pacification, as in other contexts in Brazil, deeply affected the Kaingang. Its results are seen in the historic registers of the state governments, in the reports of the Indian Protection Service and also in ethnographies conducted at the time. Anthropologists such as Herbert Baldus and

\footnotetext{
37 Precisely, 13,772 hectares remain, according to a study by Almeida (2015), who located the document “Terreno Reservado para os Índios, no município de Chapecó, Estado de Santa Catarina, Ministério do Trabalho, Indústria e Comércio, Serviço de Proteção aos Índios em 1934, Microfilme 379. Fundo SPI, Museu do Índio/FUNAI, Rio de Janeiro. Acervo LA".

38 Until today the names of the Indian delegates are known by the Kaingang in Paraná. There are reasons to believe that they have been people with a strong presence in the lives of the indigenous people. To understand this approximation it is interesting to pay attention to the analysis of the indigenist bureaucracy presented by Souza Lima, for whom the position of the delegate was a "type of administrative title that granted an unpaid individual power to act under the command of the service without resources to act" (Souza Lima 1992:164).

39 As many researchers have reported, the Kaingang shamans and healers, known as kuiã, were harshly persecuted to the degree to which the implantation of the system of the Indian Protection Service advanced. Many had their homes burned and were expelled from their lands. According to anthropologist Kimiye Tommasino "the kuiã were tied to the trunk and physically punished, or 'whipped' as they usually say" (Tommasino 1995:168).
} 
Lévi-Strauss were among the Kaingang in Paraná in the 1930 and described the critical conditions in which these communities lived.

Baldus, who in 1933 was among the Kaingang of Palmas, in southwestern Paraná, where he analyzed the cult to the dead and registered in amazement the effects that the global economic crisis of 1929 had on the indigenous economy:

the Kaingang of Palmas survived mainly by gathering erva-mate. Mate is no longer exported from their region. It was uniquely surprising to hear the Indians use the word crisis" (Baldus 1979 [1937]:15).

Lévi-Strauss was in northern Paraná in 1935. This was the beginning of the settlement of the region that is now one of Brazil's most important centers of agribusiness. Lévi-Strauss' impressions were published in Tristes Tropiques, and did not spare criticisms of the "ephemeral experience of civilization" imposed on the indigenous by the project for integration to "modern life".

There was at the hamlet of São Jerônimo, which was my base, a metalworking shop, a sawmill, a school, a pharmacy. The post regularly received tools: axes, knives, nails and distributed clothes and blankets. Twenty years later these efforts were abandoned. Leaving the Indians to their own luck, the Protection Service demonstrated the indifference of which it was the object by the part of government (it would later regain a certain authority) (Lévi-Strauss, 1957, p. 159).

His comments also include a sad finding about the territory and population:

The reserve at São Jerônimo encompassed approximately 100,00o hectares, inhabited by 450 indigenous [people] grouped in 5 or 6 villages. Before leaving, the statistics of the post allowed me to gauge the destruction caused by malaria, tuberculosis and alcoholism. Ten years ago the total births did not exceed 170, while infant mortality alone reached 140 individuals (Lévi-Strauss, 1957, p. 163).

The words of Lévi-Strauss and Baldus present a general idea of the results of the territorial confinement and of the political and administrative "pacification" constructed upon the tutelary power of the state. In this context, the indigenous areas officially marked were officially reduced.

In the 1940's, the reduction in the indigenous areas was part of state and federal policy. In 1945, under Decreto no 7.692, the government of President Getúlio Vargas began a drastic process of reduction of the areas reserved to the Kaingang in the Tibagi river basin. The São Jerônimo reserve dropped from 34,00o to 5,00o hectares, and was divided into two distinct areas, the current São Jerônimo Indigenous Land and the Barão de Antonina Indigenous Land. In 1949, the state government of Moysés Lupion signed an agreement with the federal government seeking to regularize all of the indigenous areas in Paraná. Anthropologist Kimiye Tommasino (2002) demonstrated that, based on the argument for the need to make viable lands for colonization, the Indians lost an average of $90 \%$ of their lands. The area of Apucarana dropped from 54,000 to 6,300 hectares and Queimadas from 26,000 to 1,700 ha (although later expanded to 3,771 ha). The criteria that supported this official reduction was explained in the text of the Agreement of 1949:

Considering the indigenous population that now exists in each one of these Posts and adopting as a basic criteria for the respective sizes an area of 100 (one hundred) hectares per indigenous family of 5 (five) people and another 500 (five hundred) hectares for the location of the Indigenous Post and its facilities, the state of Paraná will definitively concede, for the complete ownership of the tribe, the following areas encompassed in the limits of the current reserves: 6,300 (six thousand three hundred) hectares in the region of Apucarana; 1,700 (one thousand and seven hundred) hectares in the region of Queimadas; 7,200 (seven thousand and two hundred) hectares in the region of Ivaí, 2,00o (two thousand) hectares in the region of Faxinal; 3,870 (three thousand and 
eight hundred and seventy) hectares in the region of Rio das Cobras and 2,560 (two thousand five hundred and sixty) hectares in the region of Mangueirinha (Novak2014:1750).

The Agreement of 1949 confirmed the colonial project for population concentration and territorial restriction of the indigenous peoples of Paraná. Living on reduced portions of their lands, the Kaingang continued to confront the dramatic impositions of official indigenous policy. At all the indigenous lands, Indigenous Posts of the Indigenous Protection Service were installed. Beginning with the concentration at the "Central Villages" or "Villages at the Post" the process of "institutionalization of dependency" was consolidated (Tommasino, 2002). With the reduced areas and the indigenous concentrated around the "Post", the Kaingang chiefs, the På̃íMág, were submitted to the authority of the "Chief of the Post". In this period, the person with the most important political position of the Kaingang came to negotiate and be controlled by the lesser of the authorities of the Indigenous Protection Service. This involved, as João Pacheco de Oliveira (1988) found for the Ticuna ethnographic context, an imbalance in the dynamic of the relationships between the policy among the indigenous peoples and the indigenous policy of the Brazilian state.

With the control over Kaingang policy, the Fág, the araucária angustifólia, was definitively transformed into the Pinheiro do Paraná [Paraná pine] at the sawmills installed by the Indigenous Protection Service (SPI). In the memory of the Kaingang, the time of the SPI was the time of the Panelão [big pot] labor system, when the indigenous people worked in collective harvests administered by the chief of the post and on work days only received food served at the Panelão. The episodes of this cruel exploitation live in the memory of many, such as Dona Jurema of the Mangueirinha Indigenous Land:

I remember, I also worked, I suffered a lot. We did not even have clothes. I would go with only one outfit to work, and I would leave with the same clothes to any place I wanted to go. Working only for the lieutenant, clearing land with a hoe. We did not have any more clothes. Clearing, planting rice, husking rice, we had no rest breaks (...) we cleared six alqueires to plant rice, we did not rest. The panelão only fed us corn meal, at times with pork fat and at times without. We had to eat, we were working. Those who were our bosses are no longer living, there was the now deceased Marcelino Oliveira, and the deceased José Hiláudio, known as Jeca. They were our bosses. Those three, God forbid, we could not stop for one minute, we could not rest. [...] Those of us who were weaker, the boss would shout at us, and we obeyed. My father, José Ferreira, he was sick, had a cough and also went to work, he was sick and he would work sick. ${ }^{40}$ (Castro 2011:44).

In Rio Grande do Sul the indigenous lands were also the object of state government action before the creation of the Indian Protection Service. In 1909, the agency responsible for the Directory of Lands and Colonization created the Fraternal Protection Service of Indians of Rio Grande do Sul. ${ }^{41}$ With the Fraternal Protection linked to the Secretariat of Public Work Business the state government, from 1911 to 1918, demarked eleven areas for the Kaingang, eleven toldos ${ }^{42}$ : Inhacorá, Guarita, Nonoai, Serrinha, Votouro, Erechim Ventarra, Lagoão, Ligeiro, ${ }^{43}$ Carretero, Fachinal and Caseros. These toldos were located in the northern part of the state in the Uruguay River basin. The demarcations were part of the land policy of the agency responsible for the demarcation of the lots, villages and rural infrastructure for the population of immigrant farmers. The territorial confinement of the Kaingang was therefore an integral part of state policy.

The demarcations in Rio Grande do Sul did not make a direct reference to the chiefs or indigenous authorities as in Paraná. But the Kaingang leaders frequented the capital of the state at the beginning of the

\footnotetext{
40 Interview granted to anthropologist Paulo Afonso de Souza Castro in 2011 (Castro, 2011).

41 The concept of fraternal protection to the indigenous was aligned with the positivism of the government of the Republican Party of Rio Grande do Sul and with the perspective of integration for the work defended by the Service for Indian Protection and Location of the National Worker (SPILTN).

42 Toldo: this is a generic term that comes from the Spanish word tolderia. It was widely used in Rio Grande do Sul in the nineteenth century and early twentieth century to refer to indigenous encampments.

43 The Ligeiro Indigenous Land was the only area in Rio Grande do Sul reserved by action of SPI.
} 
century, where they were received in audiences with authorities to "file complaints against the persecutions of which they were constantly victims by the intrusions that sought to dislodge them from their lands" (Bringmann 2015:78). The complaints did not change the direction of the ethnic confinement policy as made clear in the text of the report of the Secretariat of the Directory of Lands (1929):

Nomad and instable by nature it is not the nature of the savage to colonize their land as does the immigrant and much less is it their custom to provide themselves with clothing and food. On the reserves on terras devolutas which were respected for the exclusive use of the Indians, various toldos are formed in S. Rosa, Palmeira,

Erechim and Lagôa Vermelha; on them the state government maintains guardians who should provide all their needs; nevertheless there are frequent incursions of entire groups that go to the offices of the Commissions to seek clothing, blankets, food and tools. Within the budget resources annually voted, the respective assistance has been made, but apparently there is a lack of better inspection and even of a certain catechism, which has the objective, of at least avoiding that these remnants of the original races of the state be decimated by disease and alcoholism. As the toldos are reduced year by year, their joining in one or two in each Commission is indicated, where all the material, moral and better social assistance would be provided (Bringmann 2015: 89).

In addition to the confinement policy, the Kaingang territoriality in the north of the state was pressured by the political disputes of the 1920's. As registered in the report of the Fraternal Protection Service of 1925: "the last seditious movements of 1923 and 1924, also disturbed this service considerably, because they found the toldos of our Indigenous located in the northern zone, which was one of the hardest hit by the sad consequences of the spirit of disorder" (Fernandes 2005:38). Many Kaingang reported the loss of their lands in these events.

They were expelled in the revolt of the Chimangos and the Maragatos. They told the now deceased grandfather that they must leave, because they would meet for war. They offered dried meat for the Indians to leave. One group went to Lageado. Another went to Tico-tico. Meanwhile, the poor fóg (whites) took advantage and entered here. They also had nothing. [TI Votouro] ${ }^{44}$

In 1941 the Fraternal Protection Service was terminated and the administration of the areas reserved to the indigenous came under the control of the federal Indigenous Protection Service (SPI). As in the Agreement between the SPI and the Paraná state government, in 1949, the Rio Grande do Sul state government reduced the lands reserved to the indigenous, designating areas for the creation of forest reserves. ${ }^{45}$ In the early 1960 s, the areas reserved to the Kaingang were, once again, deeply affected by the state land policy through the popularly known Agrarian Reform of Brizola. All of the areas officially reserved to the indigenous by the state between 1911 and 1918 were affected by this process. Some were completely subdivided and disappeared from the territorial ordering of Rio Grande do Sul and the Indigenous Protection Service (this is the case of the current Indigenous Lands of Ventarra, Serrinha and Monte Caseros). Others were drastically reduced, with their populations concentrated in the villages around the indigenous posts. For what remained of the reserved lands, the indigenous policy of the Indigenous Protection Service took responsibility for implanting sawmills and controlling the work and production of the Kaingang under the Panelão system. The reports about those times are in the memories and narratives of the indigenous and also occupy an important part of the research and ethnographies.

In the Kaingang village of Inhacorá (RS) the oldest reported that one of the Indians, dressed in an army uniform and on a camouflaged jeep, watched the indigenous workers, armed with a shotgun. They mainly planted

\footnotetext{
44 Narratives with indigenous people interviewed and published in the territorial identification studies for the Votouro-Kandoia Indigenous Land (Fernandes, 2005).

45 Decree $\mathrm{n}^{\circ} 658$ de 10/03/1949 destined twenty-six thousand $(26,000)$ hectares for the creation of forest reserves on the lands of the Toldos Nonoai and Serrinha
} 
wheat, which was sown and reaped by hand, but also corn and beans. There was a time to begin the work and a time to end. And at lunch, they had to get on line to earn a portion of food based on beans and flour. Meat was served only once a week, in insufficient quantity (Veiga 2006:5).

In Santa Catarina the only area reserved for the Kaingang at the beginning of the twentieth century was the current Indigenous Land of Xapecó. With its limits reduced in name of third party rights, these Kaingang confronted the same violence inflicted in the neighboring states. In 1941, the Indian Protection Service created the Xapecó Indigenous Post. As part of the territorial concentration policy, in 1948 the Kaingang who lived in the Toldo Imbu were removed by force from their homes and taken to the Indigenous Post of Xapecó. The presence and action of the Xapecó Indigenous Post provoked changes that affected the social organization and insertion of the Kaingang in the regional context. Anthropologist Silvio Coelho dos Santos described the period that followed the installation of the Indigenous Post:

A few years after the installation, the Indigenous Post already moved towards a corporate organization, exploring the erva maté on the reserve and conducting an annual harvest. (...) The post was engaged in a market economy, especially the cultivation of wheat and corn (...) the benefit that the Indians received, however, was minimal, and on most occasions it was not solicited by them or used, because they rarely practiced their own agricultural activity (...) Since 1948 they began to locate on the reserve various settlers, especially Italians (...) the Indigenous granted the local settlers the lands they traditionally occupied (...) the presence of the settlers who leased in the area created new opportunities for the use of indigenous labor (...) In its "situation as a company" the Indigenous Post was dedicated to exploration of forest resources in the indigenous area, particularly the pine trees. The Post came to install its own sawmill (...) The devastation of the forest reserves of the indigenous area was practically total. The regional lumber companies, which for a long time were resentful of the scarcity of raw material, came to work 24 hours a day. Sixty thousand pine trees, approximately, were cut down on the indigenous reserve (Santos 1970: 63-66).

The detailed and broad anthropological perspective of this researcher who is one of the most important references for indigenous studies in Southern Brazil, leaves no doubt that in those years the confinement project attained its most dramatic point. All the indigenous reports about this period attest that this population was subordinated to a state of slavery, in which they worked in agriculture and extraction of lumber from what was their own lands, in exchange for food and clothes: the 'panelão system'. ${ }^{46}$ 'In keeping with the Indigenous Income $e^{47}$ policy, the employees of the Indian Protection Service authorized and at times encouraged the extraction of lumber by private parties and introduced lease contracts. The economic exploration of the natural resources and of the labor force of indigenous families, administered by representatives of the indigenous agency at the cost of physical punishment and threats, drastically degraded the quality of the lands of the indigenous areas at the same time that it made viable and institutionalized the occupation and sub-division of significant parts of the lands officially reserved to the Kaingang. The Kaingang were confined around the indigenous posts.

\footnotetext{
46 About the panelão system and the economic exploitation of the indigenous lands it is important to consult recent studies conducted by researchers from the Laboratory of Indigenous History (PPGH/UFSC), coordinated by professor Ana Lucia Nötzold. Among other important contributions, these studies have revealed that at the archives of the Museu do Índio, SPI receipts and contracts are filed that made official the practice of leasing and sale of lumber on Kaingang lands.

47 The focus of the policies of the Indian Protection Service in the 1950 and 1960's was above all "the search for increased extraction of indigenous income, i.e., resources generated from the indigenous assets the centralized control of which the SPI would seek to expand (Souza Lima1995:293).
} 


\section{Retakings: the cleansing of indigenous lands}

In the mid 1970s, the Kaingang began the process of retaking their lands. This is an extremely complex phase of the process of ethnic territorialization in southern Brazil. On one hand the restructuring of official indigenous policy was underway in the context of the military government's modernization and internationalization project. On the other, episodes of insubordination arose to contest the Kaingang's weakened political power, in association with social movements.

Bureaucratically inefficient, from the perspective of indigenous income, since the 1950's the Indian Protection Service was the target of charges of corruption and deviation of resources. In name of investigating irregularities, in the first years of the military government, the Ministry of the Interior established the Investigative Commission of the Indian Protection Service (portaria 239/1967). The results of the Commission have only recently been analyzed in depth, ${ }^{48}$ documenting the cruelty of the SPI agents. In relation to the Kaingang, the Commission identified the following violations of rights practiced by the Indigenous Posts: beatings, torture, incarceration, slave labor, illegal lumbering, land leasing and deviation of funds. ${ }^{49}$ Despite the work of the Commission, in the context of the time, the extinction of the Indian Protection Service was not treated as a consequence of the investigation. It was perceived as a demand of the state bureaucracy, in light of the international context, which sought to modernize the relationship of the Brazilian state with indigenous peoples. In 1973, this process led to the promulgation of the Statute of the Indian, Law 6001..$^{50}$

In parallel to the reorganization of official indigenous policy, social movements rose in Brazil that defended the indigenous peoples. Organizations, at first linked to the Catholic Church, such as Operation Anchieta (OPAN), ${ }^{51}$ created in 1969, and The Indigenist Missionary Council (CIMI), ${ }^{52}$ created in1972, began to work directly with the indigenous communities. Aligned with the terms of the Barbados Declaration of $1971,{ }^{53}$ the agenda of the social movements was, and still is, the self-determination of the indigenous peoples. Thus, the social movements held various assemblies with indigenous leaders throughout the country, and sought to approximate other political sectors and universities. In Southern Brazil, after the indigenous assemblies, in 1977 in the state legislative assembly in the capital of Rio Grande do Sul was held the seminar "The Surviving Indians of the South". As anthropologist Silvio Coelho dos Santos affirmed:

It was the first time that, during the military regime, an expressive number of anthropologists, lawyers, religious people, indigenists and indigenous and civil leaders joined to express and defend the rights of the minority peoples. From this seminar resulted the founding of the National Association of Support for the Indian (ANAI) [and] the Pró-Índio of São Paulo and Rio de Janeiro (Santos 2005:73).

While the social movements recruited intellectuals and politicians to support the "Surviving Indians of the South" the Kaingang, reacting to the situation of hardship and exploitation within their lands, began

\footnotetext{
48 This commission was led by federal prosecutor Jáder Figueiredo Correia, who produced the Relatório Figueiredo [Figueiredo Report] which only recently came to be analyzed under the realm of the National Truth Commission, created in 2011. The exception is the study entitled "Vítimas do Milagre" [Victims of the Miracle], by anthropologist Shelton Davis who in 1978 made the Relatório Figueiredo an important source in his analyses about the relations between development, modernization of the state and indigenist policy in Brazil (Azola 2017).

49 The analyses of the reports of this commission are still very recent but already have stunning results, as demonstrated by the data and analyses published in an article by Fabiano Azola (2017), entitled "Relatório Figueiredo e os Índios no Sul do Brasil”[The Figueiredo Report and the Indians in Southern Brazil."

50 The extinction of the Indian Protection Service and the rise of the National Indian Foundation (Funai) in 1967, even if it also met a need to confer, on the international plane, positive visibility to the apparatuses of state power in Brazil - a result of the importance of outside financing for the transformations that they sought to implement - must be understood as part of a more general movement of redefinition of the state bureaucracy (Souza Lima, 1995: 298).

51 Currently entitled Operação Amazônia Nativa [Native Amazon Operation]

52 Linked to the National Confederation of Bishops of Brazil (CNBB)

53 The Barbados Declaration was signed by anthropologists from Latin American countries governed by military dictatorships. The terms of this declaration emphasize the responsibilities of the state, the religious missions and anthropology to support the self-determination of indigenous peoples. The sole Brazilian to sign the declaration was Darcy Ribeiro.
} 
their uprisings. The assemblies of leaders and the indigenist mobilizations transformed the local demands into the most important cycle of the struggle for territorial rights in Southern Brazil. The initial mark of this process was the expulsion of three thousand small farmers from the Indigenous Reserve of Nonoai, in Rio Grande do Sul. As the Kaingang report, in a period of five days, the Indians of Nonoai, with the support of relatives from other lands, burned the rural schools and, armed with clubs, bows and arrows and some guns, evicted the farmers who occupied their lands. ${ }^{54}$ With the retaking of their lands the Kaingang rehabilitated the power of their Pã’i Mág, their political leaders, their chiefs. The strengthening of the political power was, once again, the Kaingang response to the territorial confinement policy. The social movements certainly had an important role, but the Kaingang themselves were definitively the protagonists of the retakings. In the words of the chief of the Nonoai, Nelson Xangrê, “ They are people who taught the leaders of 1978 a lot. But I always had my thoughts about how to lead the struggle. They did not make the war, we did". ${ }^{55}$

Figure 05 Photo by Assis Hoffman, 1978. Source: Instituto Socioambiental, identified as one of the moments of the retaking of Nonoai.

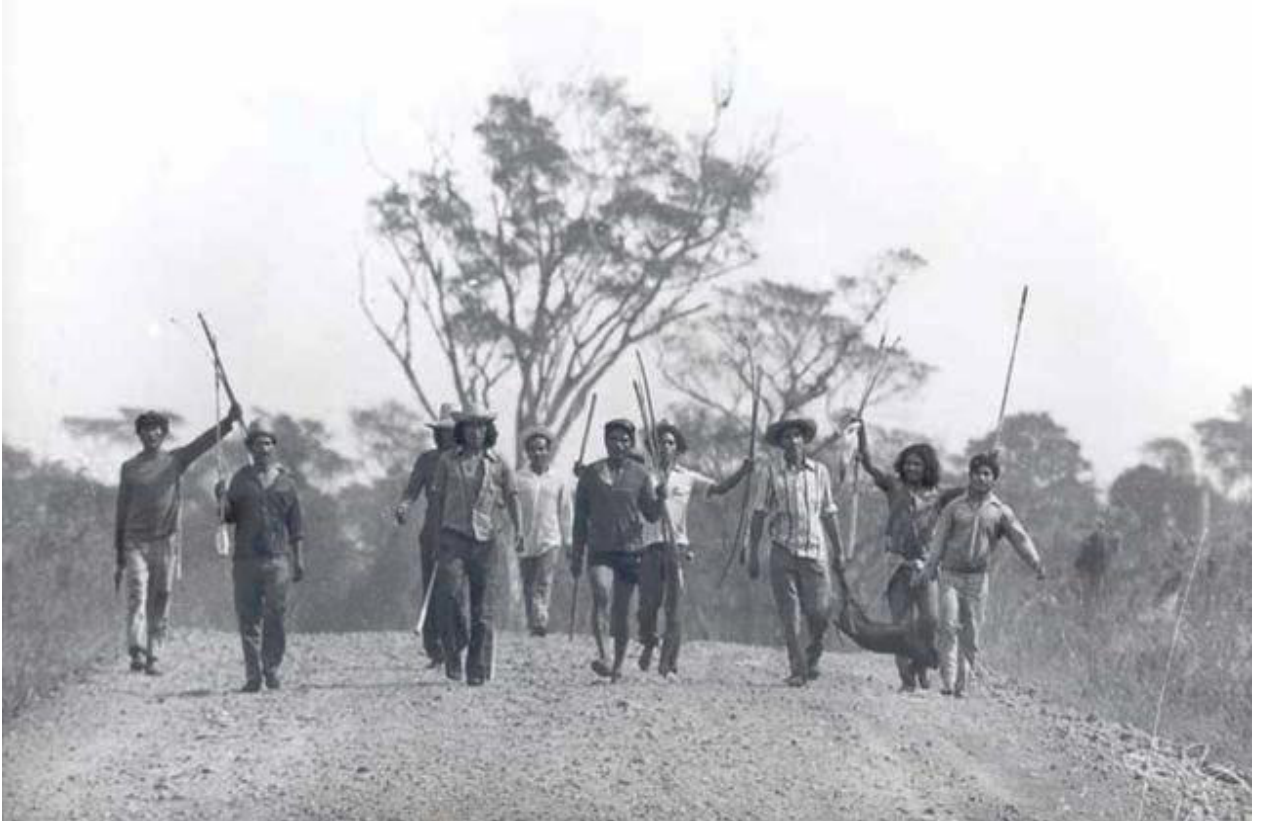

In this context the statements of the Kaingang leaders are impressive. In 1979 the documentary film “Terra de Índios" [Land of the Indians], by Zelito Vianna, registered the determination with which the indigenous peoples undertook the retaking movement. The statement by Ângelo Cretã, chief of the Mangueirinha at the time, emphasizes that the Kaingang were united and dedicated to recovering their lands.

Since we began that and won, we went all the way, why not clear other areas? We went to Nelson [Xangrê] to help take the intruders from there. The situation there is dificult, but if we win at Rio das Cobras, we win here [at Mangueirinha], and at Chapecó and Nonoai. Even if someone dies, many people will remain. We will attack hard and clear the indigenous lands (Ângelo Cretã apud Castro 2011:112).

\footnotetext{
54 There is a still little studied connection between the retaking of the Nonoai Indigenous Land and the rise of the Movimento Sem Terra [Landless Farmworkers Movement]. Under supervision of professor Silvio Coelho dos Santos, Serrano (1994) wrote a final course project about this issue. According to Serrano the peasants expelled "inaugurated the struggle of the landless in Rio Grande do Sul. Camped out at the Nonoai indigenous land, at the location that became known as the 'Encruzilhada Natalino', they underwent a process of political awareness, also recognizing themselves as victims of a perverse land ownership system. Some were resettled in Rio Grande do Sul, others in Mato Grosso and a few in the Amazon, in failed Agro-Village projects. Those who remained at the Encruzilhada Natalino, five years later occupied the Fazenda Anoni, in a paradigmatic action of the Landless Movement” (Serrano 1994:50). 
In this documentary, the statement by Nelson Xangrê, the chief who led the removal of the peasants at Nonoai, confirmed the intensity of this first large retaking movement:

The thing is if we want to resolve the case of the whites, we must act, form a group and remove the whites from the area. To expel them from the area (...). The major problem that we have is the invader, the people are concerned, first it was the SPI that leased our lands and after this came the invasion (...). The Indians never had guns and the whites came armed. (...) There were a lot of pine trees in this region and now there are just remnants, I even blame the authorities, they are authorizing the cutting of timber. (Nelson Xangrê, apud Castro 2011:113).

The sizes of the retakings vary, but it is common to hear from the Kaingang that in 1978 , seven hundred farmers were expelled from the Xapecó Indigenous Land (SC) and five hundred were expelled from Manguerinha (PR). Since then, in the past forty years, the retakings have become constant, reinserting ethnic territorialization into discussions about the ordering of landownership in southern Brazil. In all regions, voices emerged that were amplified by the power of the indigenous movement condemning the cruelty of the processes of confinement and exploitation.

In Rio Grande do Sul, since 1986, after the recognition of the Rio da Várzea and Iraí Indigenous Lands, there was a sequence of retaking processes initially involving the Indigenous Lands of Cacique Doble (1991), Carreteiro (1991), Ligeiro (1991), Guarita (1992), Inhacorá (1991), Monte Caseros (1994), Ventarra (1994) Votouro (1997) and Serrinha (1997). In Santa Catarina, where until 1986 the state only recognized the Xapecó Indigenous Land for the Kaingang, various lands were recognized: Toldo Chimbangue (1986), Toldo Pinhal (1996), Toldo Imbu (1999) and Aldeia Condá (2001). In Paraná, beyond the expulsion that took place in the indigenous land of Mangueirinha in 1978, the pressure from the Kaingang resulted in the regularization of the existing indigenous lands of Rio das Cobras (1984), Marrecas (1984), Barão de Antonina (1985), São Jerônimo da Serra (1985) and Queimadas (1996). An analysis of each one of these processes demonstrates the intensity of the mobilizations and the diversity of methods that the Kaingang have used to retake their lands and recover their ability to influence decisions about the ethnic territories in the three states of southern Brazil.

In northern Paraná, in 1979, the Kaingang mobilized to remove settlers from the Indigenous Land of Barão de Antonina (Tommasino, 1994). In this period, the indigenous families were living on less than 72 hectares, the equivalent of less than $2 \%$ of the total area of the indigenous reserve - recalling that the area reserved to the indigenous had already been reduced by about $85 \%$ by the Agreement of 1949 , when it dropped from 34,000 to 5,000 hectares. The retaking of this land took place in two steps: the first in 1979, with the removal of the intruders from the so-called Gleba I; and the second in 1985 with the retaking of Cedro.

João Maria Rodrigues, known as Tapixi, chief at the time of the retaking of Cedro, narrated details of the strategy that was developed to retake the area.

After the people retook Gleba I we saw that it was possible to have the lands again. I spent two years thinking about how we could retake Cedro. For two years I did not tell anyone! Then one day I asked my nephew who knew how to draw very well. I called him and had him make a drawing of an Indian with a bow and arrow. It was to be a very large illustration that I would use on a sign. He still did not know what I would do. When it was ready we put it on the road to Cedro and we wrote a message that said that the squatters had to leave by a given day. There was the message and the design with the Indian with a bow and arrow. Time passed and nothing happened...Then they tore down the sign. So we made another and set another deadline. But Funai said it would hold a meeting to deal with us. They brought people from Incra and other authorities to negotiate another deadline. We gave another deadline, but when it was about to expire they called another meeting. But then I had already thought about what to do. Two days before the day set I warned the relatives from Apucaraninha, Laranjinha and São Jerônimo to come give support. We could not ask much time before so that no one would release the information. Then came the day of the meeting, people from Funai came with that discussion of 
delaying the deadline again, I said that I agreed, but that I couldn't hold back the community. I had thought that the relatives from the other communities had abandoned us, but then people began to arrive. They came and circled the people from Funai and Incra. We held them and told the newspapers. The bosses of these workers came and the retaking of Cedro took place with no one getting hurt! (56 $^{6}$

As in Nonoai (RS), the community of Barão de Antonina mobilized a process among the villages, and with the weight of this mobilization, was able to recover its lands, clear two lands, as chief Cretã said. These examples also illustrate the two lines of action used by the Kaingang: open confrontation and seizing of state employees.

Even today in Paraná, the indigenous movement does not question the territorial reductions imposed by the Agreement of 1949. The demands of the Kaingang focused on the re-establishment of their officially recognized territories and on access to benefits from public policies. In the Tibagi River basin the indigenous mobilization was, and still is, involved with guaranteeing territorial rights related to the implantation of hydroelectric projects. The federal public ministry filed a public civil suit in 2006 so that all of the territory in this river basin be considered as traditional indigenous territory. In 2011, the federal court issued a favorable decision. This decision, by recognizing the historic and traditional dimension of the territory, brought important implications for the implantation of development projects that would be required to consider the presence of the Kaingang as a group with specific rights linked to the Tibagi River basin. ${ }^{57}$ A practical and immediate consequence is that the impacts of these projects will have to be considered beyond the limits of the officially demarcated indigenous lands - an ethnic dimension of territory that goes beyond that of the confinement policy.

In Rio Grande do Sul, Kaingang retakings led to the state creating a working group to discuss the indigenous question. In 1997, the reports of this working group included a comparative chart with detailed information: an official tabulation of the expropriation of the indigenous lands demarcated at the beginning of the twentieth century XX..$^{8}$

\begin{tabular}{|c|c|c|}
\hline Indigenous Land & $\mathbf{1 9 1 8}$ & $\mathbf{1 9 9 6}$ \\
\hline Carreteiro & 600,72 ha & 600,72 ha \\
\hline Ligeiro & $4.517,86$ ha & $4.517,86$ ha \\
\hline Guarita & $23.183,00$ ha & $23.183,00$ ha \\
\hline Votouro Guarani & 741,00 ha & 280,00 ha \\
\hline Votouro Kaingang & $3.104,00$ ha & $1.440,00$ ha \\
\hline Nonoai & $34.908,00$ ha & $14.910,00$ ha \\
\hline Faxinal Cacique Doble & $5.576,33$ ha & $4.349,53$ ha \\
\hline Inhacorá & $5.859,00$ ha & $1.054,62$ ha \\
\hline Ventarra & 753,00 ha & 0,00 ha \\
\hline Monte Caseiros & $1.003,74$ ha & 0,00 ha \\
\hline Serrinha & $11.950,00 h a$ & oo,oo ha \\
\hline Total & $92.196,65$ ha & $50.335,73$ ha \\
\hline
\end{tabular}

The state government concluded that after more than twenty years of demands, the Kaingang lands in Rio Grande do Sul remain significantly smaller than the lands demarcated by the state between 1911 and 1918 . The government recognized that the indigenous lands had been settled by state initiatives and determined that

\footnotetext{
56 Personal communication to anthropologist Paulo Góes. São Jerônimo da Serra Indigenous Land. 2011.

57 In addition to the Mauá hydroelectric dam there are four hydroelectric dams to be installed on the Tibagi River; railroad lines are being built, electrical transmission lines. Two pulp factories are in operation.

58 Concluding Report of the Working Group, created by Decreto no 37.118 of December 30, 1996 (Silva 2014: 2101).
} 
indemnifications should thus be paid to the settlers who, after all, had purchased their lands in good faith. In this context of conflict and negotiation, the State Indian Council ${ }^{59}$ was created. Initially formed by representatives of five government secretariats and two indigenous representatives (one Kaingang and one Guarani) the council was transformed in 1999 into the State Council of Indigenous Peoples of Rio Grande do Sul (CEPI), and came to have twenty council members from the government and forty two indigenous (20 Kaingang, 20 Guarani and 2 Charrua ${ }^{60}$. In the plan for political representation of the Council, the indigenous, in fact recovered an influential position, which altered the discussions about the Kaingang's territorial rights in the state.

With the mobilizations of the indigenous movement and with the discussions of the state council within the structure of the state, the indigenous question in Rio Grande do Sul transcended the limits of the retakings, coming to involve territorial rights in light of the living conditions within the officially demarcated lands. With a constantly growing population, living in reduced areas demarcated by the confinement policy, the Kaingang in Rio Grande do Sul have called for the demarcation of new areas through encampments outside the areas demarcated in the early twentieth century. There are now more than twenty Kaingang encampments, which pressure the National Indian Foundation to execute the processes of territorial identification and delimitation. Leading each encampment is a Kaingang leader who maintains contacts with social movements and state agencies. The relationship between the leaders of the encampments and the leaders of the indigenous lands is marked by contradictions. At times they are allies and at times opponents. The political tensions raised by the encampments in Rio Grande do Sul place on the agenda the challenges the state faces in the process of Kaingang ethnic territorialization.

In Santa Catarina the Kaingang indigenous lands are concentrated in the western region. The processes of land retakings began on the Xapecó Indigenous Land in the late 197os with the expulsion of seven hundred settlers. ${ }^{6}{ }^{6}$ The struggle for the retaking of the Xapecó Indigenous Land highlighted the precarious situation in which the other communities lived in the state: the Kaingang at the margins of the Irani River (Toldo Chimbangue and Toldo Pinhal), the Chapecó River (Toldo Imbu) and in the city of Chapecó itself (the Condá village).

On the margins of the Irani River, the Toldo Chimbangue and Toldo Pinhal, were not officially recognized in the early twentieth century. Nevertheless, there are Indigenous Protection Service records that confirm that the Irani Toldo was attended at different periods of official indigenous policy. The absence of the state in the protection of the territorial rights of the Kaingang on the right bank of the Irani River (Toldo Chimbangue) was denounced by the studies of anthropologist Silvio Coelho dos Santos. In 1979 his surveys indicated that the hydroelectric dams planned for the Uruguay River would lead to the flooding of 1,556 hectares of indigenous lands, with the compulsory dislocation of approximately 310 indigenous (Santos \& Aspelin, 1979). The Kaingang of Toldo Chimbangue were among those affected. Based on the denunciations and in response to the pressure exercised by the Missionary Indigenist Council (CIMI), in 1986, 988 hectares were demarcated along the Irani River. This was a provisory demarcation, because the tensions between the Kaingang and the farmers, unions, associations and local politicians, made the demarcation of the land identified unviable at the time. Only in 2000 did FUNAI conclude the studies for the definitive demarcation. In 2007, after twentyone years, the Kaingang of Toldo Chimangue had their territorial rights finally recognized.

On the left bank of the Irani River, the Kaingang of the Toldo Pinhal were living in a similar situation. In 1993, part of their territory ( 893 hectares) was demarcated. At the time they reported that the size of the

\footnotetext{
59 Decreto no 35.007 December 9, 1993

6o For an analysis of CEPI in the political context of Rio Grande do Sul see Londero 2015.

61 This was also the period of revival of the ritual of the cult to the dead, the Kiki. Prohibited by the Indian Protection Service and condemned by religious missionaries who frequented the Kaingang lands, the Kiki ritual was abandoned in the 1940s. The revival of this ritual in the context of the retaking of lands is a complex issue, which involves the valorization of cultural forms, simultaneously, as ties to tradition, as support for solidarity to relatives and as resources of ethnic identification.
} 
lands totaled nine thousand hectares. In the report of 1993 FUNAI affirmed that the demarcation of 893 hectares was provisory. This situation generated an unexpected consequence. Some of the rural farmers occupying the lands were suffering because of the uncertain situation. Since those lands were identified as potential indigenous lands, there was a sharp decrease in public and private investments in the region (the municipal governments no longer conducted road maintenance, local commerce declined, bank financing for farming was cut). In 2001, the situation, which was dramatic for those small farmers, caused the farm families to go to court to require FUNAI to conclude the studies about the limits of the Toldo Pinhal. Paradoxically, FUNAI, pressured by the farmers, established a technical group in January 2002 to conduct a new study of the limits of the Toldo Pinhal. In 2007 the studies were approved and the territorial limits declared, totaling approximately five thousand hectares. The definitive demarcation was still not conducted, because the studies are being challenged by the same farmers who filed suit to require FUNAI to conclude the studies. Despite the apparent contradiction, the farmers, supported by rural unions and municipal governments, question the indemnifications. Unlike the retaking processes in Rio Grande do Sul, the indemnifications of these lands follows the procedure of the federal government which does not pay for the lands, only for improvements. Today, the territory of the Kaingang community at Toldo Pinhal is recognized by the state, but the demarcation has still not taken place. The Kaingang await the officialization of their territorial rights. The farmers await the recognition of their rights, their indemnifications. The tensions, however, do not wait.

Toldo Imbu was part of the land reserved for the Kaingang in 1902, by Decree no 7 of the Paraná government. It is thus a territorial right that was lost to accommodate the rights of third parties. As in all the cases, this was a very violent process. The report of Kaingang Vicente Fokãe, who was born at Toldo Imbu, is illustrative and irreplaceable. Vicente, who was interviewed in May 2000, when he was 88 , stated:

It was drizzling and suddenly a truck arrived with the people from ... it was a tough man, Wismar Costa Lima, it was 1948 he took the truck, I don't know if he rented it or if they bought it, but I think that they paid, then he spoke with the one who was the sergeant, a type of chief right, they called him the captain. Then they got them. He ordered them to come together, but some did not want to. But with force they tied up João Batista who is the brother of uncle Otávio, they were grabbing them and hitting them inside the truck, tying their hands behind their backs and binding their feet. So we saw them and we were already at Pinhalzinho [a village in the Xapecó Indigenous Land]. When we found out we left, right. There was a road there. So we couldn't turn back. The others left everything they had: plants, bees, forest, 'monjoio', animals, hogs, ducks, beehives, gardens, they left the garden without harvesting, beans, chickens, there was everything. Then it was just a look after they came, who they left at the post, at the post de Campina da Jacutinga, jailed there. Then others went to see the things that stayed behind, that had already gotten nearly everything, in the barn and they had set fire to the houses, they burned the houses. So this part that I know is from 1948, was transferred, a part of it was lost but not us...waiting" (Vicente Fokãe, interview with anthropologist Ricardo Cid Fernandes, in May 200o).

Many of these lands in the Toldo Imbu are now occupied by the urban portion of the municipality of Abelardo Luz, which makes their return an even more conflictive process. In 1999, the National Indian Foundation established a technical group to mark this indigenous land. They identified 2,30o hectares approved by FUNAI and declared it to be indigenous property by edict of the Ministry of Justice. Despite the pressure from the Kaingang, which since 1999 had occupied an area of the municipality, the land situation of Toldo Imbu was still not regularized. The municipal government of Abelardo Luz conceded some houses in the area that was retaken, where the Kaingang families lived. In addition to the memory of the presence in the location, the studies by FUNAI, and the declaration of the Ministry of Justice, the demarcation of Toldo Imbu won a favorable decision from the Federal Court of the $4^{\text {th }}$ Region. In 2012, the 
judge emphasized: "it is well known that Indians had always lived around the old São Pedro farm, which was broken up in properties for the plaintiffs, and the indigenous reserve of Xapecó was even demarcated there by Funai, in favor of this Kaingang indigenous community (...) The study and the historic literature from the region thoroughly demonstrates this presence." ${ }^{\prime 2}$ Neither the land, nor the right to land were completely reconquered. In improvised residences provided by the municipal government, the Kaingang awaited the judgment of the appeals to the federal Superior Court of Justice.

The conviviality with cities is also at the origin of territorial rights, demands and conquests of the Kaingang Indigenous Land Aldeia Condá. Unlike the others, this Indian Land was acquired through the settlement of the Kaingang families who had lived in the city of Chapecó, it is thus considered an Indigenous Reserve. Living in the main city of western Santa Catarina, these families did not submit to the confinement of the indigenous policy and did not take refuge in areas of difficult access on the margins of rivers. They stayed in their traditional territory, "invisibly" accompanying the growth of the city of Chapecó which they continue to consider their traditional territory. The process of creation of the Aldeia Condá Indigenous Reserve began in 1998 through the constitution of a FUNAI technical group for the preparation of the "Report to Identify the Kaingang Families Resident in the City of Chapecó". This report demonstrated that for the Kaingang, the city of Chapecó is their traditional territory and that despite the attempts to remove them from the city, taking them to Nonoai (RS) and to Toldo Chimbangue (SC), they always returned.

Based on the report prepared by anthropologist Kimiye Tommasino (1998), the purchase was determined of an area of 2,300.2 hectares in the rural zone of the municipality. The area selected affected 75 farm families. In this case, even with the indemnification determined by the FUNAI procedure, the negotiations with the family farmers reached an impasse, given that they did not accept the amounts offered. The solution found was to transfer responsibility for the indemnification to the electrical sector, by making the acquisition of the Aldeia Condá Indigenous Reserve one of the conditions for issuing the environmental license of the Foz do Chapecó hydroelectric dam. ${ }^{63}$ This solution that resolved the problem from the perspective of the state, generated a difficult negotiation, because it opposed the objectives of the indigenous to other social movements like the Movement of People Affected by Dams (MAB) and the Landless Workers Movement (MST). The negotiations were difficult, but were effective for guaranteeing the territorial rights of the indigenous. In 2006, the Kaingang received the lands acquired from the electrical sector and came to live at the Aldeia Condá Indigenous Land, some fifteen kilometers from the center of the city of Chapecó, their traditional territory. The guarantee of their right to these lands stimulated the Kaingang to defend other demands such as expanded access to education and public policies that supported the construction of their own indigenous citizenship plan.

\section{Final considerations new territories}

Impeded from inhabiting the regions that support the main monuments of their territorial trajectory that dates back many centuries, limited to areas first reserved but then reduced by the state, and forced to accept sawmills, land leasers and squatters and large developments on their lands, the Kaingang have resisted and until today represent more than half of the population of the entire Jê linguistic family. They live in one of the regions in Brazil with the greatest political and economic strength of agribusiness. They have 38 indigenous lands recognized or in a process of recognition by the state and dozens of other areas about which the state land administration has not taken a position. Their leaders dialog, as did their

\footnotetext{
62 Ação Civil Pública. Processo № 5000599-41.2011.404.7202/TRF 16/11/2012.

63 This condition was made official in the Termo de Conduta [Stipulated agreement] ANEEL/FUNAI oo1/2001.
} 
ancestors, with official authorities at all levels, participate in the formulation of public policies while their intra- and inter-village dynamics remain beyond the comprehension of the fóg (the whites).

Upon analyzing the territorialization process, we take the risk of generalizing, making reference to the historic trajectories of conquest and colonization, the cruelty of the bureaucracy of confinements and to the intensity of the retaking. The result is nothing but an overview that is useful if it can help give value to the specific meaning of land to the Kaingang (gá). An ethnographic look at each situation would inevitably reveal the tensions of conviviality and conflict among different agents, discourses and powers. In all the cases, the Kaingang emphasize that their relationship with the land is one of belonging, it is umbilical. The surnames indicate a place, they belong to that land, to that location where the umbilical cord of my parents, grandparents and children are buried. ${ }^{64}$ The dialects of their language are geographically locatable, because their sociology replicates affiliation to specific locations. The land is the origin and destination of the Kaingang, on it are generated the brothers of mythic time ${ }^{65}$ and their dead return to the land, inhabitants of the underground, of the numbê. ${ }^{66}$ About the variations in their cultural forms, the Kaingang have dialoged and dialog with the state power that makes their territories official.

The cycle of retakings that began in the late 1970 s can be characterized as a movement in the direction of the repositioning or recovery of the territorial rights granted by the state. It is very clear that the Kaingang sought to and are seeking to recover their rights, associated to areas that were reserved to the indigenous in the nineteenth century and early twentieth century. Nevertheless, beyond this cycle of recovery and repositioning of rights, it is possible to identify conquests that go beyond the retakings. The occupation of political positions on the State Councils of the Indigenous Peoples of Rio Grande do Sul and federal court decisions recognizing the Tibagi River basin as traditional Kaingang territory are two concrete examples of how the cycle of retakings goes beyond the realm of the repositioning of territorial rights.

The new processes of ethnic reterritorialization, such as the encampment in Rio Grande do Sul and the villages that they form within cities, involve above all the production of new rights. In their struggle for the right to produce new territories, the Kaingang exhibit their capacity for ethnic mobilization, through political articulation among the villages, negotiations with institutions at various levels, a readiness to engage in conflict and a recourse to historic memory and to references to the cultural landscapes. Today, in processes and projects of creation of new villages, the Kaingang make new territories arise: as that in the Guaiba River basin in Porto Alegre or on the Curitiba plateau, as on the margins of demarcated lands, along trails, bus stations, in "houses of passage" in state capitals and cities of the interior. These are new struggles, to which we can see that the Kaingang people are accustomed and prepared to confront with the political resources they have constructed through experience. As in other phases of the ethnic territorialization process, the strengthening of political power is a Kaingang strategy.

Received on October 19, 2017

Approved on March 04, 2018

Translated by: Jeffrey Hoff

\footnotetext{
64 For the Kaingang, the burial location of an umbilical cord is considered an important symbol of relationship with a place, with their land of origin. Many know the locations where the umbilical cords of their ancestors are buried and of their descendants.

65 According to Kaingang mythology, the pioneer demiurges who gave origin to humanity came to the world from underground, leaving from the tops of the mountains.

66 The main Jê archeological structures in southern Brazil are funeral complexes and the main traditional ceremony of the Kaingang registered by historic and ethnographic documents is the kiki ritual, which is dedicated to ancestors.
} 


\section{Bibliographic References}

ALMEIDA, C. S. 2015. Tempo, Memória E Narrativa Kaingang No Oeste Catarinense: a tradição kaingang e a proteção tutelar no contexto da transformação da paisagem na terra Indígena Xapecó. Tese de doutorado. Unpublished. PPGH/UFSC. Florianópolis.

AMOROSO, M. 1998. Catequese e Evasão. Etnografia do Aldeamento Indígena São Pedro de Alcântara, Paraná (18551895). Tese de doutoramento. PPGAS/USP.

. et al. 2003. Do Contato ao Confronto: a conquista de Guarapuava no século XVIII. São Paulo: Expomus.

AOKI, M.T. 2013. Dois mundos em desencontro: narrativa imagética de Joaquim José de Miranda e o relatório de Afonso Botelho sobre o encontro entre índios e luso-brasileiros nos campos de Guarapuava a partir de 1771. Monografia. DEHIS/UFPR.

AZOLA, Fabiano. 2017. "O Relatório Figueiredo e os Índios no Sul do Brasil. Monografia TCC. Ciências Sociais”. UFPR. Unpublished.

BALDUS, Herbert. 1979. Ensaios de Etnologia Brasileira. Bras1lia: Ed. Brasiliana..

BALLÉE, William. 1994. Footprints of the Forest: Ka'apor Ethnobotany — the Historical Ecology of Plant Utilization by an Amazonian People. New York: Columbia University Press.

. 2013. Cultural Forests of the Amazon: A Historical Ecology of People and their Landscapes. Tuscaloosa:

University of Alabama Press.

BECKER, I.I.B. 1976. “O Índio Kaingang no Rio Grande do Sul”. Pesquisas. Antropologia, 29. Instituto Anchietano de Pesquisas. São Leopoldo.

BORBA, Telêmaco. 1908. Actualidade Indígena. Curitiba: Impressora Paranaense.

BRINGMANN, S. 2015. Entre os índios do sul: uma análise da atuação indigenista do SPI nos postos indígenas Nonoai/RS e Xapecó/SC (1941-1967). PPGHIS/UFSC. Tese de doutoramento.

CARDENAS, M.L et al. 2015. "Integrating archaeology and palaeoecology to understand Jê landscapes in southern Brazil”. Antiquity: a Review of World Archelogy,. 348(89): .

CARNEIRO da CUNHA, Manoela. 1992. "Política Indigenista no Século XIX”. In: A História dos Índios no Brasil. São Paulo: Ed. Companhia das Letras, FAPESP.

CASTRO, P. 2011. Ângelo Cretã e a Retomada das Terras Indígenas no Sul do Brasil. PPGA/UFPR. Dissertação. CORAIOLA, A. 2003. Capital do Papel: a história do município de Telêmaco Borba. Curitiba:

CORTELETTI, R. et al. 2016. Análises de grãos de amido e fitólitos nas terras altas do sul do Brasil: repensando a economia e mobilidade dos grupos proto-Jê meridionais. Cadernos do Lepaarq/UFPEL,XIII(25)::

CRÉPEAU, R. 1997. "Mito e Ritual entre os índios Kaingang do Brasil Meridional”. Horizontes Antropológicos, 3(6):173-86.

D’ANGELIS, W. 2002. Bibliografia das línguas Macro-Jê. Campinas: DL/IEL/UNICAMP.

DAVIS, Shelton. 1978. As vítimas do Milagre: o desenvolvimento e os índios do Brasil. Rio de Janeiro: Zahar.

IRIARTE, J. et al. 2013. "Sacred landscapes of the southern Brazilian highlands: understanding southern proto-Jê mound and enclosure complexes". J. Anthropology \& Archaeology, 32: 74-96.

FERNANDES, R.C. 2003. "Política e Parentesco entre os Kaingang: uma análise etnológica”. Tese de doutoramento. Unpublishsed. PPGAS/USP. . 2005. Relatório de Identificação e delimitação da TI Kandóia. Portaria FUNAI 961/PRES, (20/07/04). Unpublished. . 2006. O 15 e o 23: políticas e políticos kaigangag. Campos Revista de Antropologia. Vol 7. N.2. 27-47.

FRANCO, A. 1943. Diogo Pinto e a conquista de Guarapuava. Curitiba: Museu Paranaense.

GREGÓRIO, J. et al. 2016 "Understanding the Chronology and Occupation Dynamics of Oversized Pit Houses in the Southern Brazilian Highland”. PLoSONE, 11(7): e0158127. 
HUECK, Kurt. 2015. As florestas da América do Sul. Ecologia, composição e importância econômica. São Paulo: Ed. Polígono e Ed. UnB.

LAROQUE, J. 200o. Liderança Kaingang no Século XIX. São Leopoldo: Instituto Anchietano de Pesquisas.. LÉVI-STRAUSS, C. 1957. Tristes Trópicos. São Paulo: Editora Anhembi.LIMA, Francisco das Chagas. 1976. "Memória sobre o descobrimento e colonia de Guarpuava". Revista Trimestral do Instituto Histórico e Geográfico do Brasil,4(13). 1842. Republished at Boletim do Instituto Histórico e Etnografico Paranaense, XXXII. LONDERO, M. 2015. Democracia e participação política indígena no Estado do Rio Grande do Sul: a atuação do CEPI (1993-2014) PPGCP/UFRGS.

MABILDE, P.B.A. 1983. Apontamentos sobre os Indígenas Selvagens da Nação Coroados dos Matos da Província do Rio Grande do Sul (1836-1866). IBRASA/FNPM. São Paulo.

METRAUX, A. 1946. The Caingangues. Handbook of South American Indian. Washington: Smithsonian Institution.

MONTEIRO, John M. 1992. “Tupis, Tapuias e a História de São Paulo. Revisitando a Velha Questao Guaianã”. Novos Estudos. CEBRAP, 34: 125-135.

. 2001. Tupis, Tapuias e historiadores: estudos de história indígenas e do indigenismo. Tese de Livre Docência. Departamento de Antropologia. Unicamp. Campinas.

MOTA, L. \& NOVAK, E. 2013. "Desiguais e Combinados: índios e brancos no vale do rio Tibagi/PR”. Campos Revista de Antropologia, vol 14 n.1/2. 77-113.

MOTA, Lúcio T. 1994. As Guerras dos Índios Kaingang: a história épica dos índios Kaingang no Paraná (1769-1924). Maringá: EDUEM..

NIMUENDAJU, C. 1946. The Earsten Timbira. Tradução de Robert H. Lowie. Berkeley/Los Angeles: University of California Press.. Volume 41.

NOELLI, F. 1998. Bibliografia Kaingang: referências sobre um povo Jê do sul do Brasil. Londrina: EDUEL.

NOELLI, F. \& SOUZA, J. 2017. "Novas perspectivas para a cartografia arqueológica Jê no Brasil meridional". Bol. Museu Emilio Goeldi,12(1): .

NONNENMACHER, M. S. 200o. Aldeamentos Kaingang no Rio Grande do Sul (Século XIX). Porto Alegre: EDIPUCRS.

NOVAK, E. 2014. Territórios e grupos indígenas no Paraná: a expropriação de terras através do acordo de 1949. Maringá: ERH/UEM.

PACHECO DE OLIVEIRA, J. 1988. O Nosso Governo: os Ticuna e o regime tutelar. São Roque: Editora Marco Zero. . 1998. "Uma etnologia dos "índios misturados"? Situação colonial, territorialização e fluxos culturais". Mana. Estudos de Antropologia Social, 4(1)

REIS, J.A. 2002. Arqueologia dos buracos de bugre: uma pré-história do planalto meridional. Caxias do Sul: EDUCS. SAINT-HILAIRE, A. 1995. Viagem pela comarca de Curitiba. Curitiba: FCC.

SANTOS, S.C. 1970. A Integração do Índio na Sociedade Regional: a função dos postos indígenas em Santa Catarina.. Florianópolis: EDUFSC. . 2005. "Direitos Humanos e os direitos dos povos indígenas no Brasil". Revista Ilha, 7(1):73. .; ASPELIN, P. 1979. “Indian Areas Thereatened By Hidroelectric Projects” In: Brazil.

Copenhangen: Iwigia.

SERRANO, H. 1994. O Parque Florestal de Nonoai: os índios e os outros. Florianópolis: TCC/CFH/UFSC.

SILVA, G. Z. 2014. O governo Brizola e a questão indígena no norte do Rio Grande do Sul (1958-1962). Porto Alegre: EPHIS/PUCRS.

SOUZA, J.G. et al. 2016. "The genesis of monuments: Resisting outsiders in the contested landscapes of southern Brazil". Journal of Anthropological Archaeology, 41: 196-212. 
SOUZA LIMA, A.C. 1992. “O Governo dos Índios sob a Gestão do SPI” In: Manuela Carneiro da Cunha (ed.), História dos Índios do Brasil. São Paulo: Ed. Schwarcz. 155-173.

. 1995. Um Grande Cerco de Paz. Poder Tutela, Indianidade e Formaçao do Estado no Brasil. Petrópolis: Vozes.

TOMMASINO, Kimiye. 1995. A História dos Kaingang da Bacia do Tibai: uma sociedade Jê Meridional em

Movimento. PhD Thesis. USP.

. 1998. Relatório de Identificação das Famílias Kaingang Residentes na Cidade de Chapecó. FUNAI.

Unpublished.

. 2002. Diagnóstico Etnoambiental TI IVAI. PIEP/LAEE/UEM. Maringá. Unpublished

URBAN. G. 1992. "História e Cultura Brasileira segundo as línguas nativas" In: Manuela Carneiro da Cunha (ed.), História dos Índios do Brasil. São Paulo: Ed. Schwarcz. 87-102.

VEIGA, Juracilda. 2006. O processo de privatização da posse da terra indígena. 2006. http:/|www.

portalkaingang.org/privatizacao_juracilda.pdf (Acess on: 05/10/2017)

WEISEMANN, Ursula. 2011. Dicionário Kaingang-Português/Português-Kaingang. Curitiba: Editora Esperança.

Prof. Dr. Ricardo Cid Fernandes

Federal University at Paraná

Graduate Program in Anthropology

Contact: ricardo.cidfernandes@gmail.com

MSc. Paulo Roberto Homem de Góes

Federal University at Paraná

Graduate Program in Anthropology

Contact:prhgoes@gmail.com 